\title{
HRM Practices and knowledge transfer in MNCS
}

\author{
Minbaeva, Dana
}

Document Version

Final published version

Publication date:

2007

\section{License \\ CC BY-NC-ND}

Citation for published version (APA):

Minbaeva, D. (2007). HRM Practices and knowledge transfer in MNCS. Samfundslitteratur.

Link to publication in CBS Research Portal

\section{General rights}

Copyright and moral rights for the publications made accessible in the public portal are retained by the authors and/or other copyright owners and it is a condition of accessing publications that users recognise and abide by the legal requirements associated with these rights.

\section{Take down policy}

If you believe that this document breaches copyright please contact us (research.lib@cbs.dk) providing details, and we will remove access to the work immediately and investigate your claim. 


\title{
HRM Practices and Knowledge Transfer in MNCs
}

\author{
Dana B. Minbaeva
}

SMG WP 8/2007

September 2007 
SMG Working Paper No. 8/2007

September 2007

ISBN: 978-87-91815-08-9

Center for Strategic Management and Globalization Copenhagen Business School

Porcelænshaven 24

2000 Frederiksberg

Denmark

www.cbs.dk/smg 


\title{
HRM PRACTICES AND KNOWLEDGE TRANSFER IN MNCS
}

\author{
Dana B. Minbaeva, Ph.D. \\ Center for Strategic Management and Globalization \\ Copenhagen Business School
}

Porcelaenshaven 24, DK2000 Copenhagen Frederiksberg, Denmark

Tel. (45) 38152527. Fax (45) 38152500: Email: dm.smg@cbs.dk

\section{Forthcoming as a chapter in}

\section{Sullivan, K. (ed.) Strategic Knowledge Management in Multinational Organizations (2007)}

\begin{abstract}
This chapter introduces HRM practices that help MNCs to overcome knowledge transfer barriers (knowledge-driven HRM practices). It argues that MNCs can institute various HRM practices that impact knowledge transfer barriers associated with behavior of knowledge senders and receivers. HRM practices relevant for absorptive capacity of subsidiary employees form two groups cognitive (job analysis, recruitment, selection, international rotation, career management, training and performance appraisal) and stimulative (promotion, performance-based compensation, internal transfer, orientation programs, job design and flexible working practices). The application of cognitive HRM practices enhances the ability of knowledge receivers to absorb transferred knowledge, while the use of stimulative HRM practices increases their motivation. Temporary and permanent types of international assignments respectively influence the ability and motivation of expatriate managers to share their knowledge.
\end{abstract}

Keywords: Human Resources; Personnel; Human Resource Management; Multinational Corporations; Organizational Innovation; Organizational Learning; 


\section{INTRODUCTION}

Previous research has found that the competitive advantage that multinational corporations (MNCs) enjoy over national firms is contingent upon the MNCs' ability to exploit knowledge internally across organizational units. A common theme in this line of research is that MNCs can develop knowledge in one location and then exploit it in other locations, requiring an internal transfer of knowledge. It should not be assumed that internal knowledge transfer is ever unproblematic. The transfer impediments that have attracted researchers' attention to date are: the characteristics of the transferred knowledge (Zander and Kogut, 1995; Szulanski, 1996; Simonin, 1999a, 1999b), knowledge sources (Foss and Pedersen, 2002), absorptive capacity (Szulanski, 1996; Lyles and Salk, 1996; Lane and Lubatkin, 1998; Gupta and Govindarajan, 2000; Lane, Salk and Lyles, 2001; Minbaeva et al, 2003), and the organizational context in which the transfer takes place (Szulanski, 1996; Simonin, 1999a, 1999b; Bresman, Birkinshaw and Nobel, 1999; Gupta and Govindarajan, 2000). Taken together, the findings suggest several generalizations about what is known regarding the process of knowledge transfer and its determinants. However, there are several areas that have been bypassed, which therefore create shortcomings in our understanding of the knowledge transfer process. For example, until recently, transfer of knowledge has been rarely taken to be endogenous to organizational processes and arrangements (Foss and Pedersen, 2002). Despite an increasing interest in the subject, it is surprising how little empirical research has actually been conducted on the topic. In the conclusions of the few studies that included organizational practices (see for example, Lane and Lubatkin, 1998; Gupta and Govindarajan, 2000), we often find calls for further research on "the learning capacities of organizational units", "more explicit description of the motivation and cooperative choices of the organizational individuals", "organizational mechanisms to facilitate knowledge acquisition”, etc. This study has undertaken to address these calls by considering the following question: What human resource management (HRM) practices could 
MNCs employ to enhance knowledge transfer from the headquarters to the overseas subsidiaries

and in which combination? In particular, the chapter suggests that MNCs can institute various organizational policies and practices to overcome transfer barriers associated with knowledge transfer determinants, thereby facilitating internal knowledge transfer. It differs from the existing limited work on HRM and knowledge transfer by introducing a wider range of HRM practices and considering them as a set of interrelated activities.

To clearly present the assumed relationships between HRM practices and knowledge transfer, I start by reviewing the findings of HRM-performance research to identify HRM practices that help organizations to overcome knowledge transfer barriers. Once the question of what HRM practices are important is addressed, the next step is to determine in which combination HRM practices matter to knowledge transfer. Rather than using statistical techniques to group HRM practices such as factor and cluster analysis, it was recommended to try to theoretically identify groups of HRM practices (Guest, 1997; Delery, 1998). In this regard, literature points to the possibility to expand the framework linking HRM practices and organizational outcomes by introducing mediating variables, i.e. determinants of knowledge transfer (Minbaeva, 2007). Two determinants related to the behavior of individuals were identified in the MNC knowledge transfer literature - absorptive capacity of knowledge receivers (ability and motivation to absorb knowledge) and disseminative capacity of knowledge senders (ability and motivation to disseminate knowledge). These are considered as mediating variables in the relation between HRM practices and knowledge transfer, both of which in turn enhance the degree of knowledge transfer to the focal subsidiary.

The first set of hypotheses on the link between HRM practices and knowledge transfer examines the relationships between HRM practices and absorptive capacity of knowledge receivers (subsidiary employees). The use of cognitive HRM practices (job analysis, recruitment, selection, international rotation, career management, training and performance appraisal) is expected to be positively 
related to the receivers' ability to absorb knowledge, while the employment of stimulative HRM practices (promotion, performance-based compensation, internal transfer, orientation programs, job design and flexible working practices) is expected to enhance the receivers' motivation to absorb knowledge.

The study further investigates how four types of expatriate assignments influence the knowledgesharing behavior of expatriates in terms of their ability and motivation. It was expected that longterm assignments effect an expatriate's motivation. On the other hand, temporary assignments (short-term assignments, international commuters and frequent flyers) positively influence the expatriate's ability to transfer knowledge across the MNC.

The hypotheses were tested using a data set of 92 subsidiaries of Danish MNCs located in 11 countries.

\section{BACKGROUND}

HRM is a highly diverse and often controversial field. In this study, HRM is defined as a process of “developing, applying and evaluating policies, procedures, methods and programs relating to the individual in the organization” (Miner and Crane, 1995, p. 5). HRM is a highly dynamic process where environmental forces continually impinge on all policies, procedures, methods and programs, thereby forcing HRM to adapt. HRM practices can vary across organizations (see, for example, Pfeffer and Cohen, 1984) and countries (see, for example, Brewster, 1993).

Researchers working in the field of HRM called for the transformation of the HRM system more than a decade ago, at which time they identified support to the process of organizational learning as the key strategic task facing the HRM function in many MNCs today (Pucik, 1988). Lado and Wilson (1994) suggested that HRM practices “can contribute to sustained competitive advantage through facilitating the development of competencies that are firm specific, produce complex social 
relationships, ... and generate organizational knowledge” (Lado and Wilson, 1994, p. 699). However, few studies have recognized that the traditional prescriptions of high performance HRM practices $^{1}$ do not fit the emerging knowledge-related goals of organizations. For example, Keegan and Turner (2002) argued that formal planning and job analysis procedures were not used by knowledge-intensive firms since they were engaged in uncertain, ambiguous tasks and dealt with highly turbulent and expertise-demanding environments. They, together with later researchers, argued for a new HRM task - to be centered around the process of learning and enhance the capacity of organizational members to contribute to knowledge-related organizational goals.

To identify which HRM practices could be employed to help organizations to achieve knowledgerelated outcomes, a brief review of representative case-based and existing empirical studies undertaken by scholars from different research fields (international HRM, innovation, strategy, international business, etc.) on the link between HRM practices and various knowledge-related outcomes is necessary. My purpose is to determine what HRM practices organizations could employ to enhance knowledge-related outcomes, otherwise referred as knowledge-driven HRM practices.

Using an illustrative case study, Gupta and Singhal (1993) investigated how companies manage human resources to foster innovation and creativity. They conceptualized HRM practices along four dimensions:

\footnotetext{
${ }^{1}$ High performance/"best practices" approach aims at determining HRM practices "whose adoption generally leads to valued firm-level outcomes" (Huselid, 1995, p. 643). The findings of empirical studies on this subject are similar: either across industries or within a specific sector, the more high performance HRM practices used, the better the various performance measures, such as productivity, labor turnover and financial indicators (see for example, Huselid, 1995; Huselid, Jackson and Schuler, 1997; Delaney and Huselid, 1996; Arthur, 1994, Ichniowski, Shaw and Prennushi, 1997, MacDuffie, 1995).
} 
- Human resource planning, which includes creating venture teams with a balanced skill-mix, recruiting the right people, and voluntary team assignment. This strategy analyzes and determines personnel needs in order to create effective innovation teams.

- Performance appraisal, which includes encouraging risk taking, demanding innovation, generating or adopting new tasks, peer evaluation, frequent evaluations, and auditing innovation processes. This strategy appraises individual and team performance so that there is a link between individual innovativeness and company profitability. Which tasks should be appraised and who should assess employees’ performance are also taken into account.

- Reward systems, which includes freedom to do research, freedom to fail, freedom to form teams, freedom to run businesses, balancing pay and pride, noticeable pay raises, dual career tracks, promoting from within, recognition rewards, and balancing team and individual rewards. This strategy uses rewards to motivate personnel to achieve an organization's goals of productivity, innovation and profitability.

- Career management, which includes empowering people, leading by example, and continued education. This strategy matches employees' long-term career goals with organizational goals through continuing education and training.

Source: Gupta and Singhal (1993), pp. 41-42

Recently, international business researchers have identified the role of HRM practices in the organizational learning as one subject of inquiry. For instance, Lane and Lubatkin (1998) looked at the similarities and differences between the student and teacher firms in their study on relative absorptive capacity and interorganizational learning. Among other factors, researchers considered compensation practices and found that a firm's ability to learn from another firm depends on the relative similarities of compensation policies in the student and teacher firms. Lyles and Salk (1996) 
and Lane, Salk and Lyles (2001) reported training programs to be an important knowledge acquisition mechanism. They claimed that when properly organized the training programs are also important vehicles for establishing contacts between local and parent companies' employees, and thus promote collaboration and knowledge exchange. In Minbaeva et al (2003) an effort was made to diverge from the previous work on knowledge transfer within MNCs by integrating this stream more closely with the HRM-performance literature. The results of the study indicated that investments in the development of absorptive capacity of knowledge receivers through the extensive use of training, performance appraisal, performance-based compensation and internal communication, contribute to MNCs knowledge transfer.

Similar discussions have been undertaken in the innovation literature. Laursen and Foss (2003) investigated the link between HRM practices and innovation performance and argued that HRM practices are "most conducive to innovation performance when adopted, not in isolation, but as a system of mutually reinforcing practices” (p.249). Researchers tested the hypotheses on a large dataset of 1,900 privately owned Danish firms in both manufacturing and non-manufacturing industries. Applying principal component analysis they identified two HRM systems, which influence innovation performance. The first one consists of HRM practices, which matter for the ability to innovate. They are interdisciplinary workgroups, quality circles, systems for collection of employees’ proposals, planned job rotation, delegation of responsibility, integration of functions, and performance-related pay. The second system is dominated by firm-internal and firm-external training. The overall conclusion is that "while the adoption of individual HRM practices may be expected to influence innovation performance positively, the adoption of a package of complementary HRM practices could be expected to affect innovation performance much more strongly” (Laursen and Foss, 2003, p. 257). 
In international HRM studies, it was found out that the employment of formal HRM practices hinders flexibility, while employment of new HRM practices aimed at promoting flexibility facilitate organizational learning and innovation (Brewster et al, 2001). The use of a full range of flexible working arrangements may lead to the better innovation performance in organizations since:

- Flexible employees are more adaptive to new or unfamiliar experiences;

- Flexibility, with its emphasis on the efficient deployment of labor, increases multi-skills and cross functional knowledge of employees, granting individuals the freedom to innovate;

- Flexibility can be seen as a way of gaining the commitment of the workforce;

- Flexible organizations are more successful in building a supportive learning environment, which helps to create continuous learning opportunities.

Tsang (1999) evaluated the HRM practices adopted by 12 Singapore MNCs operating in China, taking the view of the knowledge-based and learning perspectives. He focused on the role of expatriates in replicating organizational routines in a foreign subsidiary, and concluded that effective expatriation (including selection of expatriates, pre-assignment training, rotation and their learning experience) in combination with inter-operation communication and training help in achieving knowledge diffusion within MNCs. This conclusion was later supported and further developed by other researchers focusing on expatriation (including Downes and Thomas (2000), and Bonache and Brewster, 2001).

Downes and Thomas (2000) studied expatriation in the different stages of MNCs' international experience. It was found that "in the early stages of the subsidiary establishment, the expatriate acts as a vehicle for facilitating the transfer of SOP (standard operating procedures), technical and managerial expertise, corporate philosophy, and overall 'best practices'” (p. 137). As systems and 
practices of HQ are imparted the role of expatriates may temporarily be diminished. Later, the expatriation practice picks up again as subsidiaries age increase. "It is likely that a renewed practice of expatriation is either the result of technological advancements and/or product and service innovations, which may render previous knowledge obsolete and perhaps dictate updates in subsidiary learning” (Downes and Thomas, 2000, p. 146).

Bonache and Brewster (2001) put forward propositions regarding the significant impact of knowledge characteristics on expatriation policies. They proposed that if knowledge has a tacit nature, the organization must assign expatriate employees to the foreign operation; if knowledge to be transferred among MNC units is specific, the recruitment source of expatriates will be the organization itself; if knowledge to be transferred among MNC units is complex, the duration of the assignment will be longer.

In summary, the literature indicates that there are certain knowledge-driven HRM practices, the extensive use of which enhances knowledge-related outcomes. They are job analysis, job design, recruitment, selection, career management, promotion from within, expatriation, international rotation, training, orientation programs, lateral transfer, performance appraisal, performance based compensation, and flexible working practices.

The interest of the knowledge management and organizational learning researchers in these HRM practices is extremely divergent. Not all practices receive equal attention. To illustrate this point, a review of articles with empirical evidence published in management and personnel related journals was carried out on the ABI/Inform database. The search was conducted comparing the defined HRM practices and cross searching with subjects "knowledge”, "learning organizations" and "knowledge management”. The results are presented in Figure 1, showing that training, expatriation and selection are the three HRM practices, which attracted the most attention in terms of their impact on knowledge-related outcomes. However, there are a number of other HRM practices that 
an MNC could employ to enhance knowledge-related outcomes. Therefore, more empirical investigations are needed to address other knowledge-driven HRM practices identified in the theoretical literature.

- INSERT FIGURE 1 AROUND HERE -

The next step is to determine in which combination HRM practices matter to knowledge transfer. As it was mentioned earlier the literature recommends to theoretically identify groups of HRM practices by looking at mediating variables. In this study two behavioral determinants of knowledge transfer are chosen as mediating variables in the relation between HRM practices and knowledge transfer. These are absorptive capacity of knowledge receivers (ability and motivation to absorb knowledge) and disseminative capacity of knowledge senders (ability and motivation to transfer

knowledge) (see Textbox 1). The next section investigates how HRM practices influence the behavior of knowledge receivers which in turn enhances the degree of knowledge transfer to the focal subsidiary.

- INSERT TEXTBOX 1 AROUND HERE -

\section{HRM PRACTICES AND KNOWLEDGE RECEIVERS' ABILITY AND MOTIVATION TO} ABSORB KNOWLEDGE

Taking the above recommendation into consideration, the following sections argue theoretically for the choice of HRM practices affecting absorptive capacity of knowledge receivers. As indicated in Textbox 1, absorptive capacity has two elements: prior knowledge and intensity of effort (Cohen and Levinthal, 1990; Kim, 2001). "Prior knowledge base refers to existing individual units of knowledge available within the organization” (Kim, 2001, p. 271). Thus, the employees' ability, their educational background and their job-related skills might represent the "prior related 
knowledge” which the organization needs to assimilate and use (Cohen and Levinthal, 1990). The subsidiary employees' ability to absorb knowledge is related to such factors as prior achievement, initial skills level, and aptitudes. HRM practices that influence employees’ ability have been a focus of research on high performance HRM practices for some time. The overall conclusion of those studies is much the same: HRM practices “enhance employees’ knowledge, skills, and abilities and thereafter provide a mechanism through which employees can use those attributes in performing their role” (Huselid, 1995, p. 645). Thus, organizations interested in achieving better individual ability should employ those HRM practices that aim at acquiring, developing and retaining human capital, hereafter referred as cognitive HRM practices.

Even highly skilled employees will not perform effectively if they are not motivated to do so (Huselid, 1995). Indeed, few would question that "if individuals possess the prerequisite ability to learn ... performance will likely be poor if motivation is low or absent” (Baldwin, Magjuka, and Loher, 1991, p. 52). In this context, there are HRM practices that recognize and reinforce employee behavior by providing incentives that elicit the appropriate behavior. Hereafter, these practices are referred to as stimulative ${ }^{2}$ HRM practice.

The hypotheses on the effect of cognitive and stimulative HRM practices are developed below (Hypotheses 1 and 2 respectively).

\section{Cognitive HRM Practices}

The findings of studies on the impact of cognitive HRM practices on ability are not consistent. Moreover, the majority of the studies did not examine relationships between cognitive HRM practices and employee ability. Instead, they used employee ability as a criterion for collapsing practices in a composite index. Table 1 presents the findings of high performance HRM practices

\footnotetext{
${ }^{2}$ In some studies, this type of HRM practice is referred to as "behavioral”. In this study, the word stimulative is used instead to emphasize that the HRM practices in question aim to develop the motivational part of individual behavior.
} 
research on the cognitive HRM practices. The review is supplemented by findings from recent studies on HRM and knowledge-related outcomes.

\section{- INSERT TABLE 1 AROUND HERE -}

Seven out of fourteen knowledge-driven HRM practices were often identified as being related to employee ability. These are: job analysis, recruitment, selection, international rotation, career management, training, and performance appraisal. Specifically, an analysis of the competencies needed for different positions, together with an analysis of the firm's current pool of employee competencies, helps the organization specify the desired skills and knowledge. Recruitment and selection procedures aim to bring people with the previously identified skills and knowledge into vacant positions. Training, when organized as a systematic process, helps organizational individuals master their skills and influences their development. There is extensive evidence that investment in employee training enhances the human capital of the organization, which later results in a positive relationship between employee training and organizational performance (see also Delaney and Huselid, 1996). In MNCs, international rotation helps to best allocate the individual employee's need for growth and development. Performance appraisal (or performance management) systems provide employees with feedback on their performance and competencies, and give directions for enhancing their competencies to meet the needs of the organization. An integrated part of most performance appraisal systems is the establishment of objectives and targets for career management, self-development and training of employees. Thus,

Hypothesis 1. The more the subsidiary employs cognitive HRM practices, the higher the subsidiary employees' ability to absorb knowledge.

\section{Stimulative HRM Practices}

In the research on high performance HRM practices close attention was paid to HRM practices influencing employee behavior (see Table 2). For example, Huselid (1995) defined stimulative 
HRM practices as those that "affect employee motivation by encouraging them to work both harder and smarter” (p. 637). Among these stimulative practices are formal performance appraisal, performance-based criteria for compensation, internal promotion systems based on merit, and the average number of qualified applicants per position. Organizational practices influencing employees' motivation to share knowledge have also been analyzed in some studies on HRM and knowledge. For example, Hislop (2002) suggested that HRM practices could be used to shape the willingness of employees to share their knowledge through their impact on organizational commitment. Among the HRM practices that make such an impact, Hislop (2002) named job design, performance appraisal, reward system, job security and career opportunity, among others. Minbaeva et al (2003) suggested that HRM practices such as merit-based promotion and performance-based compensation may influence the motivation of knowledge receivers by providing incentives that elicit appropriate behaviors.

\section{- INSERT TABLE 2 AROUND HERE -}

The reviewed studies are more or less in agreement regarding which HRM practices influence employees' willingness to perform (see Table 2). Among these are performance-based compensation and the use of internal promotion systems that focus on employee merit and help employees to overcome invisible barriers to their career growth (Arthur, 1994; Huselid, 1995; MacDuffie, 1995; Delery and Doty, 1996). Internal transfer, aiming at allocating and retaining the best people with their knowledge and skills, allow an organization to sustain and accumulate their human capital pool. Orientation programs are designed to help new people to adjust quicker to the new environment and become a part of the "big picture”. Flexible working practices and job design can be beneficial for such employees allowing them to balance their work and other aspects of their lives. Thus, 
Hypothesis 2. The more the subsidiary employs stimulative HRM practices, the higher the subsidiary employees' motivation to absorb knowledge.

\section{HRM PRACTICES AND KNOWLEDGE SENDERS' ABILITY AND MOTIVATION TO TRANSFER KNOWLEDGE}

In Textbox 1, the ability and motivation of knowledge senders to transfer knowledge were identified as important determinants of MNC knowledge transfer. In addition to job-related competencies knowledge senders should have the ability to articulate and communicate knowledge, stimulate the learning environment, and motivate receivers to assimilate and utilize knowledge. At the same time, the senders' willingness to share knowledge is associated with commitment and involvement in the day-to-day life of the organizational unit.

One of the knowledge-driven HRM practices identified earlier and related to the behavior of knowledge senders was expatriation. In this section, therefore, hypotheses on how different types of expatriation assignment relate to expatriates' knowledge-sharing behavior in terms of their ability and willingness to share knowledge are presented and tested.

\section{Expatriates as vehicles for knowledge dissemination}

Traditionally, expatriation has been associated with the ethnocentric approach and indicated the practice of using parent-country nationals for staffing key positions in overseas subsidiaries. The primary goal of expatriation has been control and coordination: by reallocating expatriates, parent organizations have been able to exert control and achieve global integration across subsidiaries (Edstrom and Galbraith, 1977).

The goals of expatriate assignment have been changing gradually (Evans, Pucik and Barsoux, 2002). Nowadays, the old motto of expatriation - "just get the job done" - is no longer relevant. The role of expatriates as vehicles for disseminating knowledge across MNCs' units has become a 
new area of inquiry for international HRM literature (Tsang, 1999; Downes and Thomas, 2000; Delios and Bjorkman, 2000; Bonache and Brewster, 2001). Expatriates are expected to be engaged in local staff development and support skills transfer from HQ. Some researchers argued that the knowledge-related function of expatriates is complementary to the traditional function of coordination and control. For example, Delios and Bjorkman (2000) noted that under the control and coordination function "the expatriate works to align the operations of the unit with that of the parent organization” (p.279), while the complementary knowledge function requires the expatriate to transfer the parent company’s knowledge to the foreign subsidiary under conditions "in which the parent has greater proprietary knowledge” (p. 281). Research revealed a list of possible strategic targets for expatriates in the area of knowledge transfer: to develop top talent and future leaders of the company, to improve the trust/commitment of the subsidiary, to train host-national employees in order to improve individual skills, to improve team skills, to implement knowledge practices, to develop, share and transfer best practices, and to develop an international leadership (Bonache and Fernandez, 1999; Harris, Brewster and Sparrow, 2003).

Changes in the expatriate profile and increasing awareness of relocation challenges for international managers and their families led organizations to experiment with alternative forms of expatriate assignments (Harris, 2002). The traditional (long-term) expatriate assignment is usually defined as an assignment where the international manager and his/her family move to the host country for over one year (in the majority of cases, for approximately 3 years). Alternative forms to the traditional assignment include:

- Short-term assignment: an assignment with a specified duration, usually less than one year. Family may accompany the employee. 
- International commuter: an employee who commutes from the home country to a place of work in another country, usually on a weekly or bi-weekly basis, while the family remains at home.

- Frequent flyer: an employee who undertakes frequent international business trips but does not relocate.

Source: Harris (2002), Harris, Brewster and Sparrow (2003)

The New Forms of International Working survey was carried out by the Center for Research into Management of Expatriation (Cranfield School of Management) with the purpose to increase understanding of the management issues surroundings alternative forms of international working. Key findings from the survey were that all types of international assignment, including the alternative forms of international assignment, are increasing in number, but the reasons for using each types of assignment vary (see Table 3).

\section{- INSERT TABLE 3 AROUND HERE -}

What remains largely unknown is whether different types of expatriation assignments influence knowledge transfer. As indicated, the traditional form of expatriate assignment is changing due to cost and family constraints. In addition to the traditional long-term assignment, expatriates are sent abroad on more temporary assignments. However, the literature is silent on whether the new forms of international working influence knowledge transfer. This study addresses this gap by looking at why and how four types of expatriation assignments influence the knowledge-sharing behavior of expatriates and, thereby, enhance the degree of knowledge transfer to overseas subsidiaries.

In particular, an assignment that required the relocation of the manager and his/her family for a specified period was assumed to affect expatriates' motivation. Temporary assignments (short-term assignment, international commuters and frequent flyers) would increase expatriates' ability to 
transfer knowledge across the MNCs. More detailed discussion of these relationships is presented in the next section.

\section{Permanent and Temporary Expatriate Assignments}

Harris (2002) defined a long-term expatriate assignment as an assignment where the employee and family move to the host country for a specified period of time, usually more than one year. Expatriates employed on long-term assignments are permanently stationed at the overseas subsidiary. They experience high task autonomy, greater responsibilities, and other factors, which in the behavioral literature are known as role discretion (Stewart, 1982). The greater an individuals' discretion as to "what work gets done, how it gets done and by whom", the greater the sense of responsibility the individual will feel for these decisions and the greater commitment an expatriate will exhibit (Gregersen and Black, 1992). "It seems logical that task autonomy, which is similar to role discretion, should lead to greater satisfaction, since the expatriate manager has the freedom to modify the role to fit his/her abilities” (Downes, Thomas and McLarney, 2000, p. 124). Organizational commitment originally focused on an individual's emotional attachment to an organization (Mowday and McDade, 1979). If someone has high levels of affect toward their job or organization, it could be expected that they would be motivated to perform better. Therefore, permanently placed expatriates, who are abroad for a specified duration, may show higher willingness to contribute to the organizational goals. Thus,

Hypothesis 3. The more the MNC uses permanent expatriate assignments, the higher the expatriates' motivation to transfer knowledge.

Expatriates on temporary assignments (short-term assignments, international commuters and frequent flyers) are the tools by which MNCs obtain and maintain their global knowledge to a great extent. These expatriates have a greater opportunity to learn from their experience of managing the 
subsidiaries. "People moving around the company's operations worldwide are expected to learn from each other, acquire globally applicable skills, deepen expertise and expand their networks” (Executive Report by Center for Research into Management of Expatriation, 2002, p. 7). For example, highly mobile teams of experts - trouble-shooters - are often seen on short-term assignments (Executive Report by Center for Research into Management of Expatriation, 2002). They are sent on a temporary basis to different location to work together with local employees and help them to solve a particular operational problem. They also enhance their competencies by extracting the best solutions from different locations, they increase their individual understanding and vision of international operations, they continuously increase their skills and develop competencies, they improve their language abilities, and learn how to communicate in different cultures. Thus,

Hypothesis 4. The more the MNC uses temporary expatriate assignments, the higher the expatriates' ability to transfer knowledge.

The hypotheses are summarized in the conceptual model presented in Figure 2.

- INSERT FIGURE 2 AROUND HERE -

\section{MEASURES}

Measures for high performance HRM practices were developed and very well described in Huselid (1995), Huselid, Jackson and Schuler (1995), Delaney and Huselid (1996). These studies served as the main source of inspiration. In addition, scales were adopted from the Cranet survey on International Human Resource Management (carried out in 1991, 1995, 1999). The measures for the four types of expatriate assignments were adopted from the previously mentioned survey on the New Forms of International Working, which was carried out in 2000. Measures were then crosschecked with the conclusions of theoretical papers, findings from the case studies and limited 
empirical work on the link between HRM and knowledge-related outcomes. This resulted in the list of HRM practices presented in the Table 4. The same table contains measures for mediating variables. For all variables, the understanding of the operationalization was checked during the piloting of the questionnaire.

\section{- INSERT TABLE 4 AROUND HERE -}

The hypotheses are tested on the data set of 92 subsidiaries of Danish MNCs. For the description of the survey instrument development, research strategy, data collection and sample, see Textbox 2 . SPSS statistical analysis software was used for the analyses. Descriptive statistics for variables is presented in Table 5.

- INSERT TABLE 5 AROUND HERE -

- INSERT TEXTBOX 2 AROUND HERE -

\section{RESULTS}

\section{Results for Cognitive and Stimulative HRM Practices}

The correlation matrix is presented in Table 6. There were a high number of associations among HRM practices, as was expected - 58 significant correlations of different degree out of 78 possible. Factor analysis creates a set of factors to be treated as uncorrelated variables in one approach to handling multicollinearity in regression. Following Huselid (1995), I factor-analyzed HRM practices using the principal component analysis with varimax rotation. Factor loadings for each factor are reported in Table 7.

- INSERT TABLE 6 AROUND HERE -

- INSERT TABLE 7 AROUND HERE - 
Three factors with eigenvalues more than 1 emerged from the analysis. ${ }^{3}$ As expected, Factor 1 included a range of cognitive HRM practices employed to improve the ability of knowledge receivers. The factor included job analysis, recruitment, selection, international rotation, career management, and training and performance appraisal. Factor 2 contained stimulative HRM practices aiming at enhancing motivation of knowledge receivers. The factor was composed of promotion, orientation programs, lateral transfers, and compensation. Factor 3 also contained stimulative HRM practices, namely flexible working practices and job design.

Table 8 provides examination of the relationship between the HRM practices and the ability and motivation of knowledge receivers to absorb knowledge (absorptive capacity). Unstandardized coefficients were reported. Model 1 presents the results of the regression analysis of the impact of HRM practices on the ability of knowledge receivers. The Model is statistically significant with an R-square of 0.111 . As predicted, Factor 1 (the group of cognitive HRM practices) showed a positive, significant effect on the dependent variable $(\mathrm{p}<0.05)$. Hypothesis 1 is confirmed. Model 2 tested the effect of HRM practices on the motivation of knowledge receivers to absorb knowledge. The model is significant with $\mathrm{p}<0.001$ and the R-square of 0.23 . Factor 2 - promotion, orientation, transfer and compensation -showed positive effect with strong significance $(\mathrm{p}<0.001)$. In Model 2, Factor 1 also showed a positive effect, but with the smaller significance than in Model 1 . The hypothesized effect of flexible working practices and job design (Factor 3) on the dependent variable was in the expected direction but insignificant. Hypothesis 2 is partially confirmed.

\section{- INSERT TABLE 8 AROUND HERE -}

\footnotetext{
${ }^{3}$ A common rule for dropping the least important factors from the analysis is the Kaiser criterion, by which all components with eigenvalues under 1.0 are dropped.
} 


\section{Results for Types of Expatriate Assignments}

The correlation matrix for all variables used in this section is presented in Table 9. In the correlation matrix, four types of expatriate assignments showed a high degree of associations. Some of the correlation coefficients indicated the possibility of multicollinearity (i.e. $r>0.5$ ). To uncover the underlying factor structure associated with four independent variables, they were factor-analyzed using the principal component analysis as an extraction method (following Huselid, 1995). The previous choice of factor analytic solution is proven to be useful since it provided a possibility to decrease the number of independent variables and reduced problems associated with multicollinearity. Moreover, similar to the factor analytic solution used in the previous section, this factor analysis had a confirmative rather than an explorative nature. It was expected that four types of expatriate assignments would form two groups: permanent and temporary assignments. Indeed, two factors with eigenvalues $>1$ were determined from the factor analysis. Factor 1 included temporary expatriate assignments employed to improve ability of knowledge receivers. Among these were short-term expatriates, international commuters and frequent flyers. Factor 2 was represented by one type of assignment - long-term expatriation. This type of assignment was expected to influence the willingness of knowledge senders to transfer knowledge. Factor loadings for each factor, eigenvalues and percentages of variance explained by each factor are reported in Table 10.

\section{- INSERT TABLE 9 AROUND HERE - \\ - INSERT TABLE 10 AROUND HERE -}

To test the hypotheses, regression analyses were run with permanent and temporary assignments (factor-analyzed) as independent variables. The results are presented in Table 11. Model 1 showed some statistical significance with $\mathrm{p}<0.10$ and the R-square 0.053 . The model provided support for 
Hypothesis 4: the employment of expatriates on the short-term basis, use of international commuters and frequent flyers positively influence the ability of knowledge senders to transfer knowledge $(\mathrm{p}<0.10)$. Model 2 tested the effect of permanent expatriate assignments (Factor 2) on the motivation of knowledge senders while controlling for Factor 1. The model showed higher significance with the R-square of about 10 per cent. The influence of Factor 2 (long-term assignments) was positive and significant $(\mathrm{p}<0.05)$. Hypothesis 3 was confirmed.

\section{- INSERT TABLE 11 AROUND HERE -}

\section{DISCUSSION}

HRM practices and knowledge transfer are associated, but some important aspects of this interpretation and empirical support for the link are missing. This chapter aimed to take steps towards understanding why this association exists and how various HRM practices influence knowledge transfer.

In particular, it was hypothesized that the use of cognitive HRM practices is positively related to the receivers' ability to absorb incoming knowledge, while stimulative HRM practices develop knowledge receivers' motivation. The group of cognitive HRM practices includes job analysis, recruitment, selection, international rotation, career management, training and performance appraisal, while stimulative HRM practices contain promotion, performance-based compensation, internal transfer, orientation programs, job design and flexible working practices.

Before testing the hypothesis, HRM practices were classified into the factors theoretically. The specific factor structure was then confirmed through the factor analysis. Factor analysis was not used as an exploratory technique, but rather as a method of comparing the classification initially suggested by non-statistical arguments or evidence. It was also needed to reduce a number of independent variables and to handle the multicollinearity problem. Moreover, the hypotheses were 
developed in such a way that they assumed the simultaneous effect of HRM practices on the dependent variable and not the effect of individual practices. Such an assumption was recommended in the literature since HRM practices applied in combination were found to have a greater effect on organizational outcomes than the sum of the individual effects from each practice alone (Ichniowski, Shaw and Prennushi, 1997). Results of the factor analysis indicated the existence of three groups of HRM practices conducive to the behavior of knowledge receivers - the first factor was marked by higher loadings on the cognitive HRM practices (Factor 1), the second and third factors were marked by high loadings on the stimulative factors (Factor 2 and Factor 3).

To test the hypothesis, following Huselid (1995), factors were entered as independent variables into the regressions on the dependent variable. The simultaneous effect of job analysis, recruitment, selection, international rotation, career management, training and performance appraisal (Factor 1) on the receivers' ability was positive and significant $(\mathrm{p}<0.05)$. Job analysis investigates the competencies needed for different positions, based on which the needed competencies are acquired through recruitment and selection procedures. Those organizations that carry out the formal job analysis, and employ extensive recruitment and selection procedures are able to generate a pool of skilled external candidates with the desired level of knowledge and skills. Members of this pool then show the higher ability to absorb knowledge. Career management and international rotation best allocate the individual employee's need for growth and development. Performance appraisal provides employees with feedback on their performance and competencies and offers direction for enhancing their competencies to meet the changing needs of the firm. An integrated part of most performance appraisal systems is the establishment of objectives and targets for the selfdevelopment and training of employees. When organized as a systematic process, training helps to eliminate skill deficiencies identified through performance appraisals. 
The simultaneous effect of only some stimulative HRM practices at improving the receivers' motivation to absorb knowledge was positive and significant $(\mathrm{p}<0.001)$. Those organizations, which send new employees through extensive orientation programs in which they receive realistic information about the job and the organization, should expect a higher level of employee motivation to absorb knowledge. Orientation programs aim to provide general support and reassurance for the new employees, help them to cope with inevitable stresses of transition, and them adjust quickly in the new organizational environment. Promoting employees from within the firm is likely to provide a strong motivation for employees. Internal transfers aim at to better allocate individual needs for growth and development. In addition to the learning experience, employees achieve higher commitment and involvement. There is a clear linkage between individual effort and reward. Formation of performance-based compensation systems that reward employees for the value of their job and their personal contribution to organizational performance is a strong incentive. The effect of job design and flexible working practices (Factor 3) was in the expected direction but insignificant.

This chapter also considered how different types of expatriate assignments may contribute to the expatriates' ability and motivation to share knowledge. The four types of assignments are defined as long-term expatriate assignment, short-term expatriate assignment, international commuters, and frequent flyers. According to the Executive Report by the Center for Research into Management of Expatriation on the New Forms of International Working (2002), organizations appear to be making increasing use of all four types of expatriate assignments. Moreover, skills/knowledge transfer is among the main reasons for using each type of assignment. The needs for knowledge transfer were highest for long-term assignments and the lowest for frequent flyers. This chapter proceeded further, suggesting that although all four types are connected to knowledge transfer, there are different types of assignment that increase expatriates' ability and motivation to transfer knowledge to the subsidiaries. It was suggested that expatriates' willingness to transfer knowledge can be 
enhanced through the employment of long-term expatriation practices while expatriates' ability to transfer knowledge may be increased through their involvement in temporary assignments, such as short-term assignments, frequent flyers arrangements and international commuters practices. The classification of the types of expatriate assignments was verified through factor analysis.

The results of hypotheses testing indicated that by moving among several countries, expatriates deepen their knowledge, acquire globally applicable skills, become better teachers, etc. Moreover, expatriates are often expected to have both the skills to quickly and continuously transfer knowledge and be highly motivated to do so. In other words, by sending expatriates on various types of international assignment, MNCs could develop the expatriates' disseminative capacity. The analysis provided support for Hypothesis 4, namely that opting for long-term assignments influences positively expatriates’ willingness to transfer knowledge across MNCs’ subsidiaries. When permanently stationed at an overseas subsidiary, expatriates experience greater autonomy and responsibility for their employees' performance, and they exhibit greater commitment and willingness to perform better. The data analysis also confirmed the Hypothesis 3 that the expatriates' ability to transfer knowledge is positively associated with the employment of practices such as short-term expatriation, international commuters and frequent flyers.

\section{CONCLUSION}

The goal of knowledge transfer is that the receiving unit accumulates and utilizes new knowledge, a goal that is a major managerial challenge. MNCs could employ formal organizational mechanisms HRM practices - to enhance knowledge transfer. However, HRM practices do not influence knowledge transfer directly, but rather through their impact on the behavior of process participants: knowledge senders and receivers. Those subsidiaries interested in enhancing the ability and motivation of their employees to absorb transferred knowledge should employ cognitive and 
stimulative HRM practices. The employment of cognitive HRM practices, namely job analysis, recruitment, selection, international rotation, career management, training and performance appraisal, positively influences the receivers’ ability to absorb knowledge. Some stimulative HRM practices were identified as being positively related to the motivation of knowledge receivers promotion, orientation programs, transfer, and compensation.

Managing the transfer process becomes more complicated when the problems associated with knowledge transfer are considered from the international dimension. MNCs rely heavily on expatriation practices when dealing with coordination and control, breaking down the barriers between the parent company and subsidiaries, fostering the parent corporate culture, solving technical problems, and developing local talents. In addition to the traditional long-term expatriate assignments, companies engage actively in temporary international assignments such as short-term assignments, international commuters and frequent flyers. It was also found that MNCs are "unsure whether alternative forms of international assignments are helping or hindering them in meeting their global strategic objectives” (Executive report by Center for Research into Management of Expatriation on the New Forms of International Working, 2002, p. 1). The results of this study argue that MNCs may consider applying different expatriation practices depending on whether the aim is to increase expatriates' willingness or ability to transfer knowledge to the subsidiaries. Expatriates' willingness to transfer their knowledge can be enhanced through the employment of long-term expatriation practices, while their ability to transfer knowledge may be increased through involvement in short-term assignments, frequent flyers arrangements and international commuters practices.

This study has certain limitations and shortcomings. The recent literature also recommends examination of the complementarity/system effect, resulting from combination of several groups of HRM practices. In this study, the potential for complementarity was indicated by the presence of 
pairwise correlations among individual HRM practices. As expected, the correlations were generally positive and substantial. One should further investigate whether HRM practices when applied as an integrated system are mutually reinforcing and hence more effective for knowledge transfer than isolated individual practices. One possible response could be a test of a full set of interaction terms among all HRM practices while controlling for the individual practices. That solution would require a larger sample and sufficient number of degrees of freedom.

Further, in the framework offered by Szulanski (1996, 2000, 2003) and used here there are four determinants of knowledge transfer (see Textbox 1). Only two of those - related to the behavior of knowledge senders and knowledge receivers - were used in this study as mediating variables. Can HRM practices influence the characteristics of knowledge? There is some evidence that MNCs employ various organizational mechanisms given the characteristics of knowledge. For example, Brewster and Bonache (2001) addressed the question of whether knowledge characteristics explain expatriation policies. Among other things, they suggested that, "if the knowledge to be transferred among units of an MNC is tacit collective knowledge, then that transfer will involve the team” and “ if the knowledge to be transferred among units of the MNC is specific, the recruitment source of expatriates will be the company itself” (Bonache and Brewster, 2001, pp. 160-161). However, "the possibility of a reverse causality, in which organizational arrangements are chosen so that they influence the relevant characteristics, has not previously been investigated” (Foss and Pedersen, 2003, p. 13). In this study, there were significant associations between knowledge characteristics and HRM practices. Obviously, the correlation only indicates that the two variables co-vary, but never assumes that a change in one variable causes a change in another. More research is needed to understand the direction of causality of the relationships.

Another determinant of knowledge transfer - characteristics of organizational context - could also be considered as being influenced by HRM practices. Rigid organizational boundaries impose high 
barriers, which impede knowledge flows at all levels of the MNC. By employing HRM practices that remove traditional boundaries, melt the bureaucratic structures and support learning, organizations may establish the environment that promotes knowledge transfer. Indeed, Hansen (1999) concludes that the lack of direct relations between people from different departments within the organization inhibits knowledge transfer. Crossing traditional organizational boundaries is important for effective use of obtained knowledge through common projects, decentralized and autonomous groups, flexible working arrangement, etc. In the empirical studies, flexibility was found to be associated with learning opportunities, organizational climate for innovation and development, higher capacities to absorb knowledge, etc. Lyles and Salk (1996) postulates that flexibility promotes knowledge transfer process "by encouraging greater receptivity of organizational members to new stimuli from the outside, by promoting collaboration and exchanges of information within the organization and by granting members greater latitude in altering activity patterns and ways of doing things to adopt to perceived changing needs an conditions” (pp. 881882).

Finally, there is no reason to assume that the results obtained in this study are generalizable to other countries, other functional areas, etc. The model developed here does represent a reasonable starting point. But it was tested on a rather small data set of Danish subsidiaries. That definitely has some implications for the generalizability of the findings. For instance, a small sample did not offer a desirable number of degrees of freedom, which was necessary to fully explore the possible impact of control variables, such as subsidiary size (Lyles and Salk, 1996; Bresman, Birkinshaw and Nobel, 1999; Lane, Salk and Lyles, 2001; Foss and Pedersen, 2002; Minbaeva et al, 2003), industry characteristics (Lane and Lubatkin, 1998; Gupta and Govindarajan, 2000; Lane, Salk, and Lyles, 2001; Subramaniam and Venkatraman, 2001; Minbaeva et al, 2003), mode of entry (Foss and Pedersen, 2002; Martin and Salomon, 2003), ownership (Lyles and Salk, 1996; Mowery, Oxley and 
Silverman, 1996; Lane, Lyles and Salk, 2001), subsidiary age (Lyles and Salk, 1996; Bresman, Birkinshaw and Nobel, 1999; Simonin, 1999a, 1999b; Minbaeva et al, 2003) and previous experience (Simonin, 1999a, 1999b). Clearly, there is a need for a similar study with a much larger sample and countries representation, in the hope that some of the overlooked relations will be possible to consider. If that is possible, than the above mentioned limitations become opportunities to be explored. 
Figure 1. HRM practices in studies on knowledge, innovation and learning.

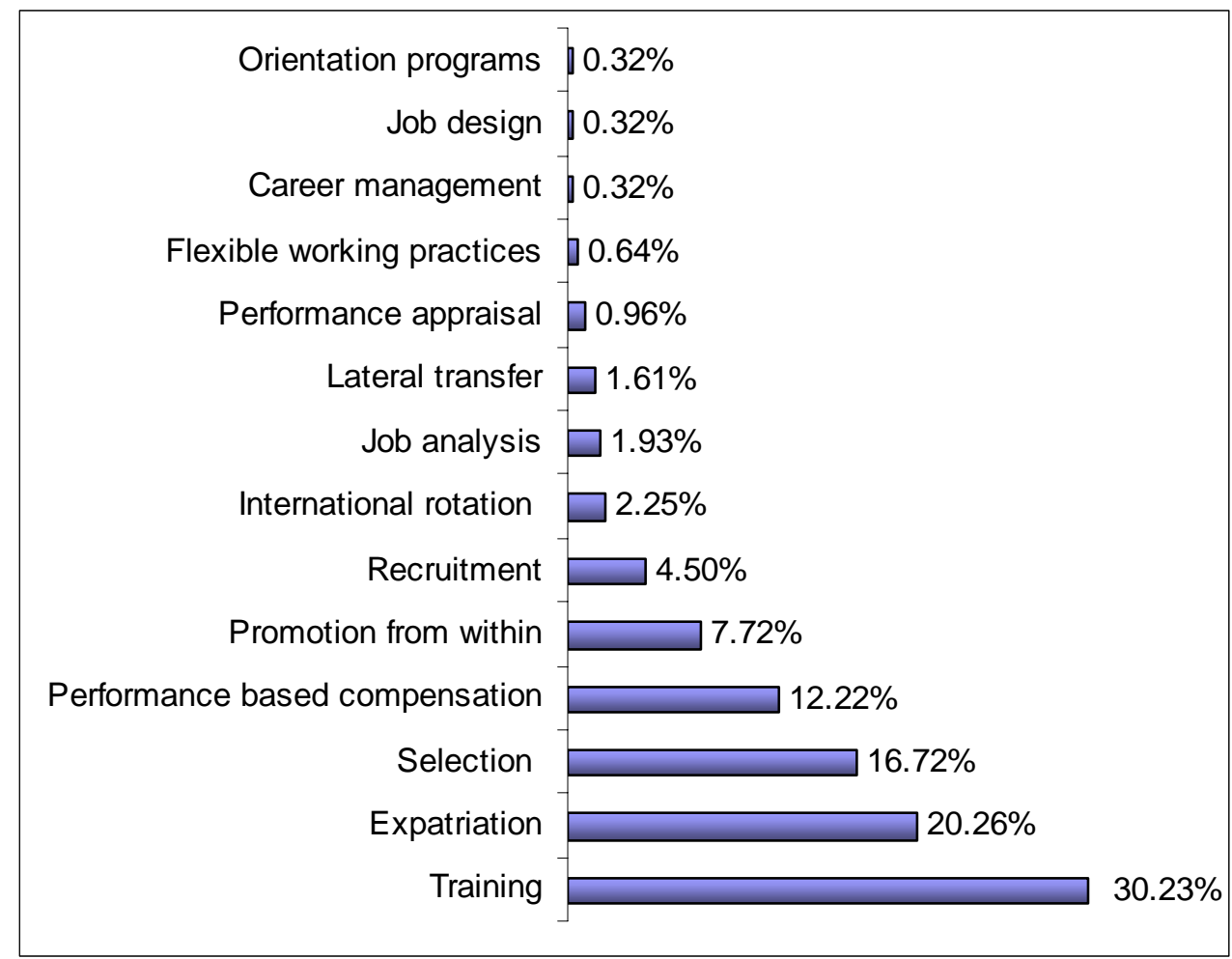

Figure 2. Conceptual model

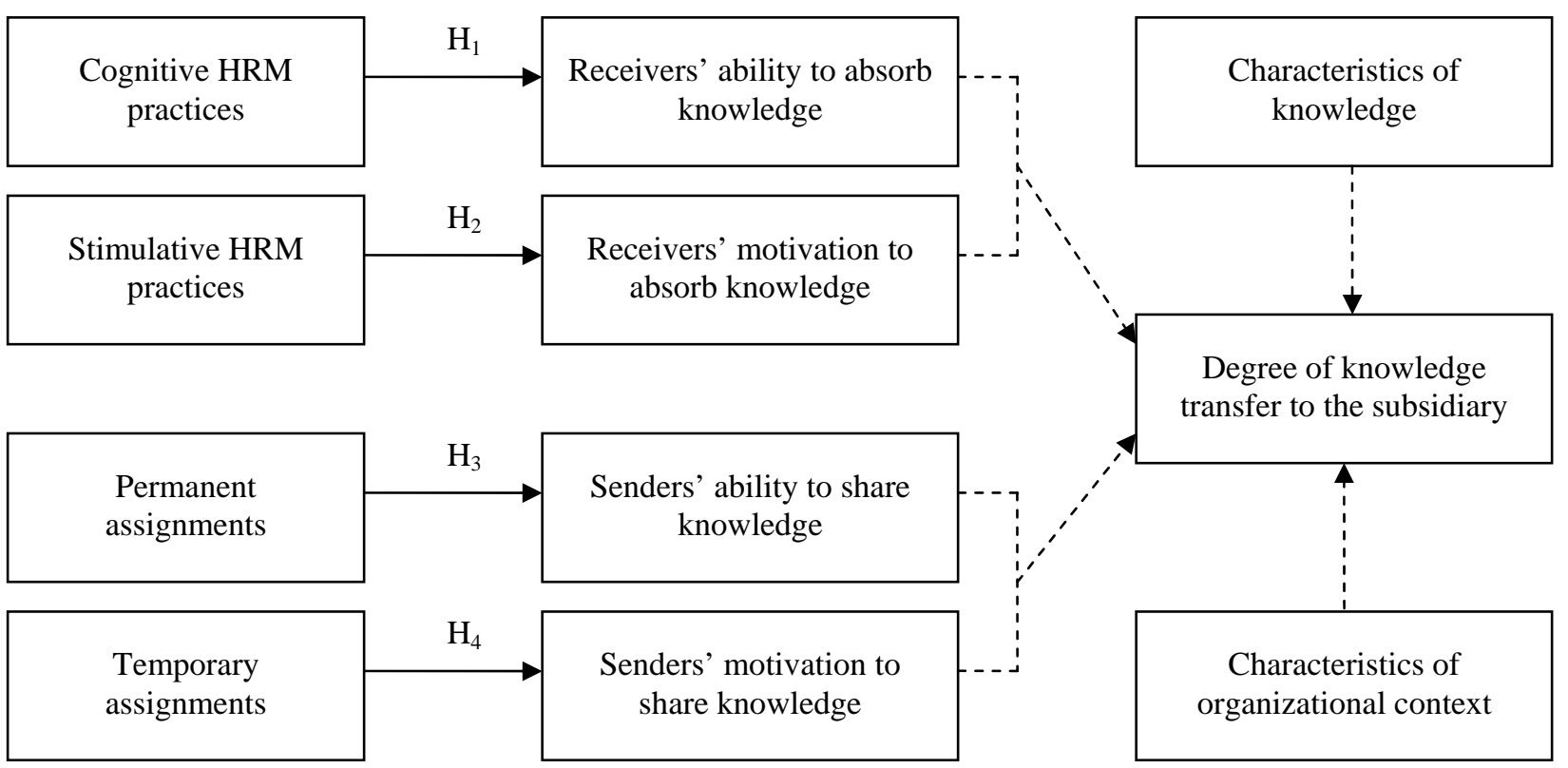


Table 1. Cognitive HRM practices

\begin{tabular}{|c|c|c|}
\hline Author(s) & HRM practices & Findings (influence on ability) \\
\hline $\begin{array}{l}\text { MacDuffie } \\
(1995)\end{array}$ & $\begin{array}{l}\text { Work teams. Problem-solving groups. Employee } \\
\text { suggestion made and implemented. Job rotation. } \\
\text { Decentralization of quality-related tasks. } \\
\text { Recruitment and hiring. Training of new } \\
\text { employees. Training of experienced employees. }\end{array}$ & $\begin{array}{l}\text { The direct impact of HRM practices on employees' } \\
\text { ability was not tested. Some of the HRM practices } \\
\text { related to skills/knowledge were linked as well to } \\
\text { motivation/commitment: work teams, problem- } \\
\text { solving groups, employee suggestion made and } \\
\text { implemented, recruitment and hiring, training of new } \\
\text { employees, and training of experienced employees. }\end{array}$ \\
\hline $\begin{array}{l}\text { Huselid } \\
(1995)\end{array}$ & $\begin{array}{l}\text { A formal job analysis. A formal information- } \\
\text { sharing program. Recruitment from within. } \\
\text { Attitude survey. Quality of work life program, } \\
\text { quality circles and labor-management teams. } \\
\text { Incentive plans, profit-sharing plans and gain- } \\
\text { sharing plans. Training. A formal grievance } \\
\text { procedure and complaint resolution system. } \\
\text { Enhanced selectivity. }\end{array}$ & $\begin{array}{l}\text { The list of HRM practices emerged from the factor } \\
\text { analysis of } 13 \text { items from the domain of High } \\
\text { Performance Work Practices identified by U.S. } \\
\text { Department of Labor. The direct impact of HRM } \\
\text { practices on employees' ability was not tested. } \\
\text { Instead, the HRM practices were collapsed to get a } \\
\text { composite index for an "employee skills and } \\
\text { organizational structures" variable (Cronbach Alpha } \\
\text { 0.67). The variable was later used to define its impact } \\
\text { on organizational performance (turnover, } \\
\text { productivity, and corporate financial performance). }\end{array}$ \\
\hline $\begin{array}{l}\text { Youndt et al } \\
\text { (1996) }\end{array}$ & $\begin{array}{l}\text { Selective staffing, selection for technical and } \\
\text { problem-solving skills, developmental and } \\
\text { behavior-based performance appraisal, external } \\
\text { equity, group incentives, skill-based pay, and } \\
\text { salaried compensation. }\end{array}$ & $\begin{array}{l}\text { The direct impact of HRM practices on employees' } \\
\text { ability was not tested. The practices were collapsed } \\
\text { into the index for the human-capital-enhancing HR } \\
\text { system with a Cronbach Alpha of } 0.68 \text {. }\end{array}$ \\
\hline $\begin{array}{l}\text { Delaney } \\
\text { and Huselid } \\
\text { (1996) }\end{array}$ & $\begin{array}{l}\text { Staffing selectivity: number of applications for } \\
\text { CORE, GSS and Managerial openings } \\
\text { (Cronbach Alpha 0.66). Training effectiveness: } \\
\text { formal job training, number of employees } \\
\text { participated in training, training effectiveness } \\
\text { (Cronbach Alpha 0.88). }\end{array}$ & $\begin{array}{l}\text { The direct impact of HRM practices on employees' } \\
\text { ability was not tested. There was suggestive evidence } \\
\text { for complementarity between training effectives and } \\
\text { staffing selectivity. }\end{array}$ \\
\hline Guest, 1997 & $\begin{array}{l}\text { Selection. Socialization. Training and } \\
\text { development. Quality improvement programs. }\end{array}$ & $\begin{array}{l}\text { The practices are conceptually defined. Instead of } \\
\text { using the term "performance", it is more sensible to } \\
\text { use the word "outcomes". HRM practices should be } \\
\text { designed to lead to HRM outcomes of high } \\
\text { performance employee commitment, high quality } \\
\text { staff and highly flexible staff. }\end{array}$ \\
\hline $\begin{array}{l}\text { Minbaeva et } \\
\text { al (2003) }\end{array}$ & $\begin{array}{l}\text { Training: the number of days of formal training } \\
\text { managerial and non-managerial employees } \\
\text { (Cronbach Alpha0.83).Competence/performance } \\
\text { appraisal: the proportion of the workforce that } \\
\text { regularly receives a formal evaluation of their } \\
\text { performance, the proportion of jobs where a } \\
\text { formal job analysis has been conducted, the } \\
\text { proportion of new jobs for which a formal } \\
\text { analysis of the desired personal } \\
\text { skills/competencies/characteristics is carried out } \\
\text { prior to making a selection decision (Cronbach } \\
\text { Alpha 0.66). }\end{array}$ & $\begin{array}{l}\text { Training has a significantly relationship with } \\
\text { employees' ability }(p<0.01) \text {. The effect of } \\
\text { performance appraisal on employees’ ability is } \\
\text { marginally significant }(p<0.10) \text {. }\end{array}$ \\
\hline
\end{tabular}


Table 2. Stimulative HRM practices

\begin{tabular}{|c|c|c|}
\hline Author(s) & HRM practices & Findings (influence on motivation) \\
\hline $\begin{array}{l}\text { Arthur } \\
(1992)\end{array}$ & $\begin{array}{l}\text { Broadly defined jobs. Employee participation. } \\
\text { Formal dispute resolution. Information sharing. } \\
\text { Highly skilled workers. Self-managed teams. } \\
\text { Extensive skills training. Extensive benefits. } \\
\text { High wages. Salaried workers. Stock ownership. }\end{array}$ & $\begin{array}{l}\text { Commitment HRM practices were characterized by } \\
\text { higher levels of employee involvement in managerial } \\
\text { decisions, formal participation programs, training in } \\
\text { group problem solving, socializing activities and by a } \\
\text { higher percentage of maintenance, or skilled, } \\
\text { employees and average wage rates. }\end{array}$ \\
\hline $\begin{array}{l}\text { MacDuffie } \\
(1995)\end{array}$ & $\begin{array}{l}\text { Work teams. Problem-solving groups. Employee } \\
\text { suggestion made and implemented. Recruitment } \\
\text { and hiring. Contingent compensation. Status } \\
\text { differentiation. Training of new employees. } \\
\text { Training of experienced employees. }\end{array}$ & $\begin{array}{l}\text { The direct impact of HRM practices on employees' } \\
\text { motivation was not tested. Some HRM practices } \\
\text { related to skills/knowledge were linked as well to } \\
\text { motivation/commitment: work teams, problem- } \\
\text { solving groups, employee suggestion made and } \\
\text { implemented, recruitment and hiring, training of new } \\
\text { employees, training of experienced employees. }\end{array}$ \\
\hline $\begin{array}{l}\text { Huselid } \\
\text { (1995) }\end{array}$ & $\begin{array}{l}\text { Performance-based compensation. Formal } \\
\text { performance appraisal. Merit-based promotion, } \\
\text { seniority-based promotion (reverse coded). } \\
\text { Number of qualified applicants per position. }\end{array}$ & $\begin{array}{l}\text { The list of HRM practices emerged from the factor } \\
\text { analysis of } 13 \text { items from the domain of High } \\
\text { Performance Work Practices identified by U.S. } \\
\text { Department of Labor. The direct impact of HRM } \\
\text { practices on employees' motivation was not tested. } \\
\text { Instead, the HRM practices were collapsed to get a } \\
\text { composite index for an "employee motivation” } \\
\text { variable (Cronbach Alpha 0.66). The variable was } \\
\text { later used to define its impact on organizational } \\
\text { performance (turnover, productivity and financial } \\
\text { performance). }\end{array}$ \\
\hline $\begin{array}{l}\text { Delaney and } \\
\text { Huselid } \\
\text { (1996) }\end{array}$ & $\begin{array}{l}\text { Incentive compensation: performance related } \\
\text { earnings of managers and administrators, } \\
\text { COREs and GSS (Cronbach Alpha 0.83). } \\
\text { Grievance procedure: formal procedures for } \\
\text { resolving disputes. }\end{array}$ & $\begin{array}{l}\text { The direct impact of HRM practices on employees' } \\
\text { motivation was not tested. Complementarity among } \\
\text { HRM practices influencing employees' motivation } \\
\text { was not observed. }\end{array}$ \\
\hline Guest, 1997 & $\begin{array}{l}\text { Single status. Job security. Internal promotion. } \\
\text { Individualized reward systems. }\end{array}$ & $\begin{array}{l}\text { The practices are conceptually defined. Instead of } \\
\text { using the term "performance", it is more sensible to } \\
\text { use the word "outcomes". HRM practices should be } \\
\text { designed to lead to HRM outcomes of high } \\
\text { performance employee commitment, high quality } \\
\text { staff and highly flexible staff. }\end{array}$ \\
\hline $\begin{array}{l}\text { Hislop } \\
(2002)\end{array}$ & $\begin{array}{l}\text { Fair decision-making. Appraisal and reward } \\
\text { system. Job design. Type of organizational } \\
\text { culture. Job security. Internal promotion and } \\
\text { career opportunities. }\end{array}$ & $\begin{array}{l}\text { The motivation of employees to share their } \\
\text { knowledge may be shaped by their level of } \\
\text { organizational commitment. The list of HRM } \\
\text { practices influencing commitment is conceptually } \\
\text { defined. }\end{array}$ \\
\hline $\begin{array}{l}\text { Minbaeva et } \\
\text { al (2003) }\end{array}$ & $\begin{array}{l}\text { Merit-based promotion: the opportunity to be } \\
\text { promoted to positions of greater pay and/or } \\
\text { responsibility within the subsidiary, the } \\
\text { importance on merit for promotion decisions, the } \\
\text { extent to which upper-level vacancies are filled } \\
\text { from within (Cronbach Alpha } 0.63 \text { ). } \\
\text { Performance based compensation: the proportion }\end{array}$ & $\begin{array}{l}\text { Performance-based compensation is highly } \\
\text { significant }(\mathrm{p}<0.001) \text { determinants of employees' } \\
\text { motivation. }\end{array}$ \\
\hline
\end{tabular}




\begin{tabular}{|l|l|l|}
\hline $\begin{array}{l}\text { of employees who have the opportunity to earn } \\
\text { individual, group or company-wide bonuses, } \\
\text { whether the company uses performance-based } \\
\text { compensation and whether the compensation } \\
\text { systems are closely connected to the financial } \\
\text { results of the subsidiary (Cronbach Alpha 0.61). }\end{array}$ & \\
\hline
\end{tabular}

Table 3. New Forms of International Working: Survey findings

\begin{tabular}{|c|c|c|c|c|c|c|}
\hline \multirow[t]{2}{*}{$\begin{array}{c}\text { Type of } \\
\text { assignment }\end{array}$} & \multirow[t]{2}{*}{$\begin{array}{l}\text { Number of } \\
\text { employees }\end{array}$} & \multicolumn{2}{|c|}{$\begin{array}{c}\text { Changing patterns and } \\
\text { trends in the number of } \\
\text { employees }\end{array}$} & \multirow[t]{2}{*}{$\begin{array}{c}\text { Reasons for use } \\
\text { (top 3) }\end{array}$} & \multirow{2}{*}{\begin{tabular}{|} 
Usual \\
length of \\
assignment \\
(majority)
\end{tabular}} & \multirow[t]{2}{*}{$\begin{array}{c}\text { Main problems } \\
\text { encountered }\end{array}$} \\
\hline & & $\begin{array}{c}\text { In the last } 2 \\
\text { years }\end{array}$ & $\begin{array}{l}\text { For the } \\
\text { next } 5 \\
\text { years }\end{array}$ & & & \\
\hline $\begin{array}{l}\text { Long-term } \\
\text { assignment }\end{array}$ & $\begin{array}{l}53 \% \text { of } \\
\text { respondents } \\
\text { have more } \\
\text { than } 50 \\
\text { employees on } \\
\text { this type of } \\
\text { assignment }\end{array}$ & $\begin{array}{l}62 \% \text { of } \\
\text { respondents } \\
\text { reported an } \\
\text { increase }\end{array}$ & $\begin{array}{l}48 \% \text { of } \\
\text { respondents } \\
\text { reported an } \\
\text { increase }\end{array}$ & $\begin{array}{l}\text { Skills transfer } \\
(74 \%), \\
\text { managerial } \\
\text { control }(62 \%) \\
\text { and management } \\
\text { development } \\
(60 \%)\end{array}$ & $\begin{array}{l}3 \text { years } \\
(57 \%)\end{array}$ & $\begin{array}{l}\text { Mobility } \\
\text { barriers/unwillingness to go } \\
\text { to unattractive locations. } \\
\text { Dual career/family issues. } \\
\text { Repatriation/career issues. } \\
\text { Cost } \\
\text { assignment/administration. } \\
\text { Compensation } \\
\text { package/terms and } \\
\text { conditions }\end{array}$ \\
\hline $\begin{array}{l}\text { Short-term } \\
\text { assignment }\end{array}$ & $\begin{array}{l}18 \% \text { of } \\
\text { respondents } \\
\text { have more } \\
\text { than } 50 \\
\text { employees on } \\
\text { this type of } \\
\text { assignment }\end{array}$ & $\begin{array}{l}67 \% \text { of } \\
\text { respondents } \\
\text { reported an } \\
\text { increase }\end{array}$ & $\begin{array}{l}66 \% \text { of } \\
\text { respondents } \\
\text { reported an } \\
\text { increase }\end{array}$ & $\begin{array}{l}\text { Skills transfer } \\
(69 \%), \\
\text { management } \\
\text { development } \\
(39 \%), \\
\text { managerial } \\
\text { control (12\%) }\end{array}$ & $\begin{array}{l}\text { Up to } 1 \\
\text { year }(55 \%)\end{array}$ & $\begin{array}{l}\text { Work/life balance. Difficult } \\
\text { to establish policy and } \\
\text { practice. Tax management } \\
\text { issues and compensation } \\
\text { terms and conditions }\end{array}$ \\
\hline $\begin{array}{l}\text { International } \\
\text { commuter }\end{array}$ & $\begin{array}{l}6 \% \text { of } \\
\text { respondents } \\
\text { have more } \\
\text { than } 50 \\
\text { employees on } \\
\text { this type of } \\
\text { assignment }\end{array}$ & $\begin{array}{l}52 \% \text { of } \\
\text { respondents } \\
\text { reported an } \\
\text { increase }\end{array}$ & $\begin{array}{l}50 \% \text { of } \\
\text { respondents } \\
\text { reported an } \\
\text { increase }\end{array}$ & $\begin{array}{l}\text { Skills transfer } \\
(32 \%), \text { family } \\
\text { reasons (32\%), } \\
\text { managerial } \\
\text { control (25\%) }\end{array}$ & $\begin{array}{l}\text { Up to three } \\
\text { months } \\
(15 \%)\end{array}$ & $\begin{array}{l}\text { High costs. Work/life } \\
\text { balance. Defining policy } \\
\text { terms. Tax management. } \\
\text { Cultural differences. }\end{array}$ \\
\hline $\begin{array}{l}\text { Frequent } \\
\text { flyer }\end{array}$ & $\begin{array}{l}26 \% \text { of } \\
\text { respondents } \\
\text { have more } \\
\text { than } 50 \\
\text { employees on } \\
\text { this type of } \\
\text { assignment }\end{array}$ & $\begin{array}{l}52 \% \text { of } \\
\text { respondents } \\
\text { reported an } \\
\text { increase }\end{array}$ & $\begin{array}{l}50 \% \text { of } \\
\text { respondents } \\
\text { reported an } \\
\text { increase }\end{array}$ & $\begin{array}{l}\text { Managerial } \\
\text { control (40\%), } \\
\text { skills transfer } \\
(26 \%), \\
\text { developing an } \\
\text { international } \\
\text { cadre (20\%) }\end{array}$ & $\begin{array}{l}\text { Up to one } \\
\text { week } \\
(31 \%)\end{array}$ & $\begin{array}{l}\text { Cost management. Burnout. } \\
\text { No established policies. }\end{array}$ \\
\hline
\end{tabular}


Table 4. Measures.

\begin{tabular}{|c|c|c|}
\hline Variables & Label & Description \\
\hline Job analysis & Analysis & $\begin{array}{l}\text { Please mark the number that best indicates the degree to which each } \\
\text { statement describes the HRM practices employed within your subsidiary. } \\
\text { Likert type scale ranging from } 1 \text { - never to } 5 \text { - always } \\
\text { - Job analysis identifies the required educational background, previous } \\
\text { experience, the general competency information, etc. }\end{array}$ \\
\hline Job design & Design & $\begin{array}{l}\text { - We use different approaches to job design - such as job enlargement, job } \\
\text { rotation, and team-based job design. }\end{array}$ \\
\hline Flexible practices & Flexible & $\begin{array}{l}\text { - We use flexible working arrangements - such as flextime, job sharing, and } \\
\text { part-time work - to accommodate best the individual working arrangement } \\
\text { preferences. }\end{array}$ \\
\hline Recruitment & Recruitment & $\begin{array}{l}\text { - The purpose of our recruitment procedures is to generate a pool of qualified } \\
\text { external candidates for a particular job. }\end{array}$ \\
\hline Promotion & Promotion & $\begin{array}{l}\text { - When a vacancy occurs, we carry out a search within the company before } \\
\text { turning to the various outside sources. }\end{array}$ \\
\hline Selection & Selection & $\begin{array}{l}\text { - We use various selection procedures to determine the characteristics require } \\
\text { for effective job performance. }\end{array}$ \\
\hline Orientation programs & Orientation & $\begin{array}{l}\text { - All new employees will be oriented in the philosophy, ethics, values, and } \\
\text { business priorities of the company. }\end{array}$ \\
\hline Lateral transfer & Transfer & $\begin{array}{l}\text { - Employee lateral transfer is considered a development activity and one of } \\
\text { the best ways to retain talented people. }\end{array}$ \\
\hline International rotation & Rotation & $\begin{array}{l}\text { - Local nationals are often transferred to headquarters or other international } \\
\text { operations. }\end{array}$ \\
\hline Career management & Career & $\begin{array}{l}\text { - Career development in our company represents an ongoing and formalized } \\
\text { effort of corporate management. }\end{array}$ \\
\hline Training & Training & $\begin{array}{l}\text { - Our training programs aim to provide employees with specific skills and } \\
\text { help them to correct deficiencies in their performance. }\end{array}$ \\
\hline $\begin{array}{l}\text { Performance based } \\
\text { compensation }\end{array}$ & Compensation & $\begin{array}{l}\text { - Employees are generally rewarded on the basis of the value of the job and } \\
\text { their personal contribution to organizational performance. }\end{array}$ \\
\hline Performance appraisal & Appraisal & $\begin{array}{l}\text { - The performance management system in our company has a developmental } \\
\text { purpose of providing information and direction to individuals. }\end{array}$ \\
\hline
\end{tabular}




\begin{tabular}{|c|c|c|}
\hline $\begin{array}{l}\text { Receivers' ability to } \\
\text { absorb knowledge }\end{array}$ & ReAb & $\begin{array}{l}\text { Compared to your industry competitors, how do you rate your subsidiary's } \\
\text { employees on the following dimensions ... Likert type scale ranging from } 1 \\
\text { - very low to } 5 \text { - outstanding } \\
\text { Job-related abilities } \\
\text { Overall competence } \\
\text { Please evaluate the ability of the knowledge receivers (your subsidiary's } \\
\text { employees) to absorb new knowledge. Likert type scale ranging from } 1 \text { - } \\
\text { very low to } 5 \text { - outstanding }\end{array}$ \\
\hline $\begin{array}{l}\text { Receivers' motivation } \\
\text { to absorb knowledge }\end{array}$ & ReMot & $\begin{array}{l}\text { Compared to your industry competitors, how do you rate your subsidiary's } \\
\text { employees on the following dimensions ... Likert type scale ranging from } 1 \\
\text { - very low to } 5 \text { - outstanding } \\
\text { Motivation } \\
\text { Involvement } \\
\text { Job satisfaction } \\
\text { Please evaluate motivation of the knowledge receivers (your subsidiary's } \\
\text { employees) to absorb new knowledge. Likert type scale ranging from } 1 \text { - } \\
\text { very low to } 5 \text { - outstanding }\end{array}$ \\
\hline $\begin{array}{l}\text { Long-term } \\
\text { expatriation }\end{array}$ & LTexpat & $\begin{array}{l}\text { Please mark the number that best indicates the degree to which each } \\
\text { statement describes HRM practices employed across all subsidiaries within } \\
\text { the MNC. Likert type scale ranging from } 1 \text { for no or very little extent till } 5 \\
\text { for very great extent. } \\
\text { - Presence of expatriates on long-term assignments (usually over one year). }\end{array}$ \\
\hline $\begin{array}{l}\text { Short-term } \\
\text { expatriation }\end{array}$ & STexpat & $\begin{array}{l}\text { - Presence of expatriates on short-term assignments (usually less than one } \\
\text { year). }\end{array}$ \\
\hline $\begin{array}{l}\text { International } \\
\text { commuters }\end{array}$ & ICexpat & $\begin{array}{l}\text { - Presence of international commuters (an expatriate who commutes from } \\
\text { country to country usually on a weekly basis). }\end{array}$ \\
\hline Frequent flyers & FFexpat & $\begin{array}{l}\text { - Presence of frequent flyers (an expatriate who undertakes frequent } \\
\text { international business trips but does not relocate). }\end{array}$ \\
\hline $\begin{array}{l}\text { Senders' ability to } \\
\text { transfer knowledge }\end{array}$ & SeAb & $\begin{array}{l}\text { Please evaluate the ability of the knowledge senders to transfer new } \\
\text { knowledge. Likert type scale ranging from } 1 \text { - very low to } 5 \text { - outstanding }\end{array}$ \\
\hline $\begin{array}{l}\text { Senders' motivation to } \\
\text { transfer knowledge }\end{array}$ & SeMot & $\begin{array}{l}\text { Please evaluate motivation of the knowledge senders to transfer new } \\
\text { knowledge to the rest of corporation. Likert type scale ranging from } 1 \text { - very } \\
\text { low to } 5 \text { - outstanding }\end{array}$ \\
\hline
\end{tabular}


Table 5. Descriptive statistics

\begin{tabular}{|c|c|c|c|c|}
\hline Variables & Min. & Max. & Means & St.Dev. \\
\hline Analysis & 1.00 & 5.00 & 3.30 & 1.12 \\
\hline Design & 1.00 & 5.00 & 2.57 & 1.10 \\
\hline Flexible & 1.00 & 5.00 & 2.66 & 1.23 \\
\hline Recruitment & 1.00 & 5.00 & 3.32 & 1.17 \\
\hline Promotion & 1.00 & 5.00 & 3.41 & 1.15 \\
\hline Selection & 1.00 & 5.00 & 3.20 & 1.08 \\
\hline Orientation & 1.00 & 5.00 & 3.60 & 1.20 \\
\hline Transfer & 1.00 & 5.00 & 3.37 & 1.20 \\
\hline Rotation & 1.00 & 5.00 & 2.01 & 1.10 \\
\hline Career & 1.00 & 5.00 & 2.52 & 1.24 \\
\hline Training & 1.00 & 5.00 & 3.42 & 1.03 \\
\hline Compensation & 1.00 & 5.00 & 3.49 & 1.18 \\
\hline Appraisal & 1.00 & 5.00 & 3.18 & 1.14 \\
\hline ReAb & 2.00 & 5.00 & 3.6848 & 0.52149 \\
\hline ReMot & 2.00 & 5.00 & 3.6277 & 0.62379 \\
\hline LTexpat & 1.00 & 5.00 & 2.9778 & 1.25401 \\
\hline STexpat & 1.00 & 5.00 & 2.1957 & 1.07150 \\
\hline ICexpat & 1.00 & 4.00 & 2.0769 & 1.12774 \\
\hline FFexpat & 1.00 & 5.00 & 2.4565 & 1.16178 \\
\hline SeAb & 1.00 & 5.00 & 3.2857 & 0.80672 \\
\hline SeMot & 1.00 & 5.00 & 3.1196 & 0.93577 \\
\hline
\end{tabular}


Table 6. Correlation matrix (1)

\begin{tabular}{|c|c|c|c|c|c|c|c|c|c|c|c|c|c|c|c|}
\hline & 1 & 2 & 3 & 4 & 5 & 6 & 7 & 8 & 9 & 10 & 11 & 12 & 13 & 14 & 15 \\
\hline 1.Analysis & 1.000 & & & & & & & & & & & & & & \\
\hline 2.Design & $0.379 * * *$ & 1.000 & & & & & & & & & & & & & \\
\hline 3.Flexible & -0.071 & $0.265 *$ & 1.000 & & & & & & & & & & & & \\
\hline 4.Recruitment & $0.300 * *$ & $0.261^{*}$ & 0.108 & 1.000 & & & & & & & & & & & \\
\hline 5.Promotion & $0.272 *$ & 0.083 & 0.171 & $0.282 *$ & 1.000 & & & & & & & & & & \\
\hline 6.Selection & $0.410 * * *$ & $0.262 *$ & 0.117 & $0.411^{* * *}$ & $0.464^{* * *}$ & 1.000 & & & & & & & & & \\
\hline 7.Orientation & $0.296 *$ & -0.007 & 0.123 & 0.134 & $0.316^{* *}$ & $0.343^{* *}$ & 1.000 & & & & & & & & \\
\hline 8.Transfer & $0.292 *$ & $0.264^{*}$ & 0.158 & $0.258 *$ & $0.483^{* * *}$ & $0.425^{* * *}$ & 0.124 & 1.000 & & & & & & & \\
\hline 9.Rotation & $0.178^{\dagger}$ & $0.358^{* * *}$ & $0.219^{\dagger}$ & 0.179 & 0.149 & $0.176^{* * *}$ & 0.094 & 0.114 & 1.000 & & & & & & \\
\hline 10.Career & $0.378 * * *$ & $0.273^{*}$ & $0.227^{\dagger}$ & $0.427 * * *$ & $0.375 * * *$ & $0.608 * * *$ & $0.264 *$ & $0.578 * * *$ & $0.433 * * *$ & 1.000 & & & & & \\
\hline 11.Training & $0.393 * * *$ & $0.411 * * *$ & 0.003 & $0.362 * * *$ & $0.293^{* *}$ & $0.422 * * *$ & 0.181 & $0.418^{* * *}$ & $0.306^{* *}$ & $0.390 * * *$ & 1.000 & & & & \\
\hline 12.Compensation & $0.337 * *$ & $0.349 * * *$ & 0.089 & $0.261 *$ & $0.335^{* *}$ & $0.396 * * *$ & $0.304 * *$ & $0.477 * * *$ & 0.123 & $0.385^{* * *}$ & $0.544^{* * *}$ & 1.000 & & & \\
\hline 13.Appraisal & $0.252 *$ & $0.310 * *$ & 0.043 & $0.293^{*}$ & $0.294^{*}$ & 0.661 & $0.194^{\dagger}$ & $0.531 * * *$ & $0.292 *$ & $0.560 * * *$ & $0.476^{* * *}$ & $0.440 * * *$ & 1.000 & & \\
\hline 14. ReAb & $0.259 *$ & 0.148 & -0.020 & 0.124 & 0.075 & 0.166 & 0.053 & 0.007 & -0.008 & 0.082 & 0.134 & $0.214^{*}$ & 0.111 & 1.000 & \\
\hline 15.ReMot & $0.190^{\dagger}$ & 0.004 & 0.052 & -0.079 & 0.162 & 0.162 & 0.183 & $0.384 * * *$ & 0.007 & $0.232 *$ & $0.223 *$ & $0.320 * *$ & 0.193 & $0.535 * * *$ & 1.000 \\
\hline
\end{tabular}


Table 7. Factor loading for cognitive and stimulative HRM practices

Extraction method: Principal component analysis. Varimax rotation.

$\begin{array}{llll}\text { Variables } & \text { HRM1 } & \text { HRM2 } & \text { HRM3 } \\ \text { Analysis } & \underline{0.588} & 0.234 & -0.261 \\ \text { Design } & 0.524 & 0.099 & \underline{0.527} \\ \text { Flexible } & -0.097 & 0.189 & \underline{0.897} \\ \text { Recruitment } & \underline{0.584} & 0.158 & 0.029 \\ \text { Promotion } & 0.246 & \underline{0.758} & 0.073 \\ \text { Selection } & \underline{0.606} & 0.482 & 0.038 \\ \text { Orientation } & 0.038 & \underline{0.668} & -0.136 \\ \text { Transfer } & 0.447 & \underline{0.602} & 0.206 \\ \text { Rotation } & \underline{0.528} & -0.184 & 0.375 \\ \text { Career } & \underline{0.710} & 0.366 & 0.173 \\ \text { Training } & \underline{0.665} & 0.304 & 0.015 \\ \text { Compensation } & 0.448 & \underline{0.574} & 0.204 \\ \text { Appraisal } & \underline{0.699} & 0.298 & 0.086 \\ \text { Initial eigenvalues } & 4.960 & 1.371 & 1.043 \\ \text { \% of variance } & 38.15 & 10.54 & 8.024\end{array}$


Table 8. Regression analyses for ability and motivation of knowledge receivers to absorb knowledge

\begin{tabular}{lllll} 
Variables & \multicolumn{2}{l}{ Model 1 (ReAb) } & \multicolumn{2}{l}{ Model 2 (ReMot) } \\
& $\beta$ & s.e. & $\beta$ & s.e. \\
Constant & $3.682^{* * *}$ & 0.060 & $3.693^{* * *}$ & 0.064 \\
Factor 1 & $0.155^{*}$ & 0.060 & $0.134^{*}$ & 0.065 \\
Factor 2 & 0.054 & 0.060 & $0.244^{* * *}$ & 0.065 \\
Factor 3 & -0.035 & 0.060 & 0.014 & 0.065 \\
R-square & 0.111 & & 0.230 & \\
F & $2.587^{\dagger}$ & & $6.178^{* * *}$ & \\
$* * *-\mathrm{p}<0.001, * *-\mathrm{p}<0.01, *-\mathrm{p}<0.05,{ }^{\dagger}-\mathrm{p}<0.1$ & & &
\end{tabular}

Table 9. Correlation matrix (2)
1
2
3
4
5
6

1. LTexpat $\quad 1.000$

2. STexpat $\quad 0.367 * * * \quad 1.000$

3. ICexpat $0.098 \quad 0.483^{* * *} \quad 1.000$

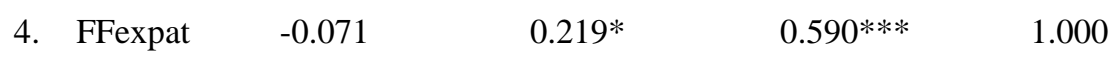

$\begin{array}{lllll}\text { 5. SeAb } & -0.008 & 0.049 & 0.183^{\dagger} & 0.201^{\dagger}\end{array}$

$\begin{array}{lllllll}\text { 6. SeMot } & 0.278^{* *} & 0.261^{*} & 0.034 & 0.091 & 0.495^{* * *} & 1.000\end{array}$

$* * *-\mathrm{p}<0.001, * *-\mathrm{p}<0.01,{ }^{*}-\mathrm{p}<0.05,^{\dagger}-\mathrm{p}<0.1$ 
Table 10. Factor loading for four types of international assignments Extraction method: principal component analysis.

$\begin{array}{lll}\text { Variables } & \text { Factor 1 } & \text { Factor 2 } \\ \text { LTexpat } & 0.332 & \underline{0.821} \\ \text { STexpat } & \underline{0.740} & 0.418 \\ \text { ICexpat } & \underline{0.880} & -0.222 \\ \text { FFexpat } & \underline{0.692} & -0.558 \\ \text { Initial eigenvalues } & 1.912 & 1.209 \\ \text { \% of variance } & 47.79 & 30.23\end{array}$

Table 11. Regression analyses for knowledge senders' ability and motivation to transfer knowledge

$\begin{array}{lllll}\text { Variables } & \text { Model 1 (SeAb) } & & \text { Model 2 (SeMot) } & \\ & \beta & \text { s.e. } & \beta & \text { s.e. } \\ \text { Constant } & 3.284^{* * *} & 0.086 & 3.101^{* * *} & 0.096 \\ \text { Factor 1 } & 0.161^{\dagger} & 0.086 & 0.200^{*} & 0.097 \\ \text { Factor 2 } & -0.096 & 0.086 & 0.211^{*} & 0.097 \\ \text { R-square } & 0.053 & & 0.095 & \\ \text { F } & 2.387^{\dagger} & & 4.538^{*} & \\ * * *-\mathrm{p}<0.001,{ }^{*}-\mathrm{p}<0.05,^{\dagger}-\mathrm{p}<0.1 & & & \end{array}$




\section{Text Box 1. Behavioral determinants of knowledge transfer}

Szulanski (1996, 2000, 2003) defines knowledge transfer as a process of dyadic exchanges of knowledge between the sender and the receiver, where the effectiveness of transfer depends to some extent on the disposition and ability of the source and recipient, on the strength of the tie between them and on the characteristics of the object that is being created (Szulanski, 2003). . Given the definition Szulanski suggests the signaling metaphor as an approach as to how classify the determinants of knowledge transfer. "This metaphor specifies the basic elements of a transfer: source, channel, message, recipient and context” (Szulanski, 2000, p. 11). There are barriers associated with the each of the named elements. They are the characteristics of knowledge, characteristics of knowledge receivers, characteristics of knowledge senders and characteristics of the relationships between the senders and receivers (Minbaeva, 2007). Two of the named variables are behavioral. They are:

\section{(1) Characteristics of knowledge receivers}

An implicit consensus exists about the importance of knowledge receiver behavior with respect to the absorption of transferred knowledge exists. The inability of knowledge receivers to absorb new knowledge (low absorptive capacity) is one of the most often cited impediments to internal knowledge transfer (e.g. Cohen and Levinthal, 1990; Lyles and Salk, 1996; Szulanski, 1996; Lane and Lubatkin, 1998; Gupta and Govindarajan, 2000; Lane, Lyles and Salk, 2001). Following Cohen and Levinthal (1990) and Kim (2001), this study defines absorptive capacity as having two elements: prior knowledge and intensity of effort. Prior knowledge includes basic skills, a shared language, relevant prior experience and up-to-date information on knowledge domains (Cohen and Levinthal, 1990; Szulanski, 1996, 2003). The term refers to the existing individual units of knowledge available within the organization (Kim, 2001). Employees need to have combinations of skills that enable them to find, acquire, manage, share, and apply knowledge that the organization needs.

The second element of absorptive capacity, as proposed by Kim (2001), is the intensity of effort. Employees’ intensity of effort is well researched in cognitive process theories, such as the expectancy theory of work motivation (Vroom, 1964). Overall, motivated employees want to contribute to organizational performance. Even though the organization may consist of individuals with significant abilities to learn, the organization's ability to utilize the absorbed knowledge will be low if employee motivation is low or absent (Baldwin et al, 1991).

\section{(2) Characteristics of knowledge senders}

Minbaeva and Michailova (2004) term the behavior of knowledge senders as "disseminative capacity". They argue that ability and willingness of organizational actors to share their knowledge are crucial to the success of knowledge transfer. Valuable knowledge is often tacit in nature. Transferring tacit knowledge requires teaching (Winter, 1987). Moreover, knowledge sharing is marked by different interpretations of the same idea, false starts, and disruptions (Zellmer-Bruhn, 2003). Therefore, knowledge senders should have well-developed abilities to articulate and communicate knowledge. These abilities could be acquired through education, training, observation, and involvement. On the other hand, knowledge senders may be capable but unwilling to share knowledge for the reasons outlined by Husted and Michailova (2002). The greater an individual's influence on the work carried out, how it is done and by whom, the greater the sense of responsibility the individual tends to feel for these decisions and the greater commitment knowledge senders exhibit. 


\section{Textbox 2. Data collection}

The Hermes CD Direct from KOB (Kobmandstandes Oplysnings Bureau) was used to construct the data set. ${ }^{4}$ The database query was initiated by selecting those firms that were headquartered in Denmark, and then the sample was reduced to those that had two or more subsidiaries abroad. The procedure resulted in a list that was crosschecked with the Børsen $500^{5}$ to ensure that the population was as complete and relevant as possible. The MNCs included in the sample were further limited to those whose subsidiaries employ more than 30 employees, as small-scale companies in general, and small subsidiaries in particular, do not utilize a wide range of formal HRM practices (Miner and Crane, 1995).

The final data set consisted of 305 Danish subsidiaries. Questionnaires were addressed to the HRM Manager/General Manager of the focal subsidiary. If the approached manager was unable to complete the survey, he/she could forward the questionnaire to a senior or middle manager with sufficient knowledge regarding the themes of this study.

A web-based survey was chosen for data collection due to the time and cost considerations. The respondents were approached by a cover letter sent via email, which explained the purpose of the survey, detailed the research process and analysis procedures, offered follow-up reports and related working papers, and provided straightforward directions completing the questionnaire. In addition, a web site was established to back up the survey. Respondents were invited to visit the web site and read more on the survey subjects and related themes. A link to the questionnaire was provided within the text of the cover letter and the survey was only available through that link, which decreased the risk of potential error.

The above strategy resulted in achieving a response rate of 30\% (92 out of 305 subsidiaries). 20 responding subsidiaries were located in Germany, 17 in the USA, 15 in Russia, 14 in China, 10 in Sweden, 6 in the UK, 6 in France and one each in Sri Lanka, Philippines, Spain and Portugal. The response rates in various countries reflects the general geographical distribution of Danish subsidiaries abroad.

${ }^{4}$ The KOB dataset is a comprehensive, continuously updated data set of domestic and international Danish firms (www.kob.dk).

${ }^{5}$ Børsen is the Danish business sector's global, national and regional newspaper. Every year the newspaper publishes an annual status report on Danish businesses (www.borsen.dk). 


\section{REFERENCES}

Arthur, J. (1994). Effects of human resource systems on manufacturing performance and turnover. Academy of Management Journal, 37, 670-687

Baldwin, T., Magjuka, R. \& Loher, B. (1991). The perils of participation: Effects of choice of training on trainee motivation and learning. Personnel Psychology, 44, 51-65.

Bonache, J. \& Fernandez, Z. (1997). Expatriate compensation and its link to the subsidiary Strategic role: A theoretical analysis. International Journal of Human Resource Management, 8(4), 457-475

Bonache, J. \& Brewster, C. (2001). Knowledge transfer and the management of expatriation. Thunderbird International Business Review, 43(1), 145-168

Bresman, H., Birkinshaw, J. \& Nobel, R. (1999). Knowledge transfer in international acquisitions. Journal of International Business Studies, 30(3), 439 - 462

Brewster, C. (1993). Developing a “European” model of human resource management. International Journal of Human Resource Management, 4(4), 765-785

Brewster, C., Communal, C., Farndale, E., Hegewisch, A., Johnson, G., \& van Ommeren, J. (2001). The HR healthcheck. Benchmarking HRM practices across the UK and Europe (Report published by Cranfield University School of Management and Financial Times). Prentice Hall

Cohen, W. \& Levinthal, D. (1990). Absorptive capacity: A new perspective on learning and innovation. Administrative Science Quarterly, 35, 128-152

Delaney, J. \& Huselid, M. (1996). The impact of human resource management practices on perceptions of organizational performance. Academy of Management Journal, 39(4), 949-969

Delery, J. (1998). Issues of fit in strategic human resource management: Implications for research. Human Resource Management Review, 8, 289-309 
Delery, J. \& Doty, H. (1996). Modes of theorizing in strategic human resource management: Tests of universalistic, contingency, and configurational performance predictions. Academy of Management Journal, 39(4), 802-835

Delios, A. \& Bjorkman, I. (2000). Expatriate staffing in foreign subsidiaries of Japanese multinational corporations in the PRC and the United States. International Journal of Human Resource Management, 11(2), 278-293

Downes, M. \& Thomas, A. (2000). Knowledge transfer through expatriation: The U-curve approach to overseas staffing. Journal of Management Issues, 12(2), 131-149.

Downes, M., Thomas, A. \& McLarney, C. (2000). The cyclical effect of expatriation satisfaction on organizational performance: the role of firm international orientation. The Learning Organization, 7(3), 122-134

Edstrom, A. \& Galbraith, J. (1977). Transfer of managers as a coordination and control strategy in multinational organizations. Administrative Science Quarterly, 22, 248-263

Evans, P., Pucik, V. \& Barsoux, J. (2002). The Global Challenge, McGraw-Hill Irwin.

Executive Report by Center for Research into Management of Expatriation on the New Forms of International Working (2002), Cranfield School of Management, the UK

Foss, N. \& Pedersen, T. (2002). Transferring knowledge in MNCs: The role of sources of subsidiary knowledge and organizational context. Journal of International Management, 8, 49-67

Gregersen, H. \& Black, J. (1992). Antecedents to commitment to a parent company and a foreign operation. Academy of Management Journal, 35(1), 65-90

Guest, D. (1997). Human resource management and performance: A review and research agenda. International Journal of Human Resource Management, 8(3), 263-276 
Gupta, A. \& Govindarajan, V. (2000). Knowledge flows within MNCs. Strategic Management Journal, 21, 473-496

Gupta, A. \& Singhal, A. (1993). Managing human resources for innovation and creativity. Research Technology Management, 36(3), 41-48

Hansen, M. (1999). The search-transfer problem: The role of weak ties in sharing knowledge across organization subunits. Administrative Science Quarterly, 44, 82-111

Harris, H. (2002). Strategic management of international workers. Innovations in International HR, 28(1), $1-5$

Harris, H., Brewster, C. \& Sparrow, P. (2003). International Human Resource Management. London: CIPD

Hislop, D. (2002). Linking human resource management and knowledge management via commitment: A review and research agenda. Employee Relations, 25(2), 182-202

Huselid, M. (1995). The impact of human resource management practices on turnover, productivity, and corporate financial performance. Academy of Management Journal, 38(3), 635-672

Huselid, M., Jackson, S. \& Schuler, R. (1997). Technical and strategic human resource management effectiveness as determinants of firm performance. Academy of Management Journal, 40(1), 171188

Husted, K. \& Michailova, S. (2002). Diagnosing and fighting knowledge sharing hostility, Organizational Dynamics, 31(1), 60-73

Ichniowski, C., Shaw, K. \& Prennushi, G. (1997). The effects of human resource management practices on productivity: A study of steel finishing lines. The American Economic Review, June, 291-313 
Keegan, A. \& Turner, J. (2002). The management of innovation in project-based firms. Long Range Planning, 35, 367-388.

Kim, L. (2001). Absorptive capacity, co-operation, and knowledge creation: Samsung's leapfrogging in semiconductors. In Nonaka, I. and Nishiguchi, T. (eds), Knowledge emergence social, technical, and evolutionary dimensions of knowledge creation (pp. 270-286). Oxford: Oxford University Press.

Lado, A. \& Wilson, M. (1994). Human resource systems and sustained competitive advantage: A competency-based perspective. Academy of Management Review, 19, 699-727

Lane, P. \& Lubatkin, M. (1998). Relative absorptive capacity and interorganizational learning. Strategic Management Journal, 19, 461-477

Lane, P., Salk, J. \& Lyles, M. (2001). Absorptive capacity, learning, and performance in international joint ventures. Strategic Management Journal, 22(12), 1139-1161.

Laursen, K. \& Foss, N. (2003). New HRM practices, complementarities, and the impact on innovation performance. Cambridge Journal of Economics, 27, 243-263

Lyles, M. \& Salk, J. (1996). Knowledge acquisition from foreign parents in international joint ventures: An empirical examination in the Hungarian context. Journal of International Business Studies, Special Issue, 877-903

MacDuffie, J. (1995). Human resource bundles and manufacturing performance: Flexible production systems in the world auto industry. Industrial \& Labor Relations Review, 48(2), 197221.

Martin, X. \& Salomon, R. (2003). Knowledge transfer capacity and its implications for the theory of the multinational corporation. Journal of International Business Studies, 34(4), 345-356 
Minbaeva, D. (2007). Knowledge transfer in MNCs. Forthcoming in Management International Review.

Minbaeva, D., Pedersen, T., Bjorkman, I., Fey, C., \& Park, H. (2003). MNC knowledge transfer, subsidiary absorptive capacity and knowledge transfer. Journal of International Business Studies, 34(6), 586-599

Minbaeva, D. \& Michailova, S (2004). Knowledge transfer and expatriation practices in MNCs: The role of disseminative capacity. Employee Relations, 26(6), 663-679

Miner, J. \& Crane, D. (1995). Human resource management: The strategic perspective. HarperCollins College Publishers.

Mowday, R. \& McDade, T. (1979). Linking behavioral and attitudinal commitment: A longitudinal analysis of job choice and job attitude. Academy of Management Proceedings. USA: AOM Atlanta Mowery, D., Oxley, J. \& Silverman, B. (1996). Strategic alliances and interfirm knowledge transfer. Strategic Management Journal, 17: 77-91

Pfeffer, J. \& Cohen, Y. (1984). Determinants of internal labor markets in organizations. Administrative Science Quarterly, 29(4), 550-573

Pucik, V. (1988). Strategic alliances, organizational learning, and competitive advantage: The HRM agenda. Human Resource Management, 27(1), 77-93

Simonin, B. (1999a). Transfer of marketing know-how in international strategic alliances: An empirical investigation of the role and antecedents of knowledge ambiguity. Journal of International Business Studies, 30(3), 463-490

Simonin, B. (1999b). Ambiguity and the process of knowledge transfer in strategic alliances. Strategic Management Journal, 20(7), 595-623 
Stewart, R. (1982). A model for understanding managerial jobs and behavior. Academy of Management Review, 7(1), 7-14

Subramaniam, M. \& Venkatraman, N. (2001). Determinants of transnational new product development capability: Testing the influence of transferring and deploying tacit overseas knowledge. Strategic Management Journal, 22, 359-378

Szulanski, G. (1996). Exploring internal stickiness: Impediments to the transfer of best practice within the firm. Strategic Management Journal, 17 (Winter special issue), 27-43

Szulanski, G. (2000). Appropriability and the challenge of scope: Banc One routinizes replication, In Dosi, G., Nelson, R. and Winter, S. (eds), The nature and dynamics of organizational capabilities. New York: Oxford University Press

Szulanski, G. (2003). Sticky knowledge: barriers to knowing in the firm, SAGE Publications

Tsang, E. (1999). The knowledge transfer and learning aspects of international HRM: An empirical study of Singapore MNCs. International Business Review, 8, 591-609

Vroom, V. (1964). Work and motivation. New York, London and Sydney: John Wiley and Sons, Inc.

Winter, S. (1987). Knowledge and competence as strategic assets. In Teece, D. (ed), The competitive challenge, Ballinger Publishing Company.

Zander, U. \& Kogut, B. (1995). Knowledge and the speed of the transfer and imitation of organizational capabilities, Organization Science, 6(1), 76-92

Zellmer-Bruhn, M. (2003). Interruptive events and team knowledge acquisition, Management Science, 49, 514-528. 


\section{SMG - Working Papers \\ www.cbs.dk/smg \\ 2003}

2003-1: Nicolai J. Foss, Kenneth Husted, Snejina Michailova, and Torben Pedersen: Governing Knowledge Processes: Theoretical Foundations and Research Opportunities.

2003-2: Yves Doz, Nicolai J. Foss, Stefanie Lenway, Marjorie Lyles, Silvia Massini, Thomas P. Murtha and Torben Pedersen: Future Frontiers in International Management Research: Innovation, Knowledge Creation, and Change in Multinational Companies.

2003-3: Snejina Michailova and Kate Hutchings: The Impact of In-Groups and OutGroups on Knowledge Sharing in Russia and China CKG Working Paper.

2003-4: Nicolai J. Foss and Torben Pedersen : The MNC as a Knowledge Structure: The Roles of Knowledge Sources and Organizational Instruments in MNC Knowledge Management CKG Working Paper.

2003-5: Kirsten Foss, Nicolai J. Foss and Xosé H. Vázquez-Vicente: “Tying the Manager's Hands": How Firms Can Make Credible Commitments That Make Opportunistic Managerial Intervention Less Likely CKG Working Paper.

2003-6: Marjorie Lyles, Torben Pedersen and Bent Petersen: Knowledge Gaps: The Case of Knowledge about Foreign Entry.

2003-7: Kirsten Foss and Nicolai J. Foss: The Limits to Designed Orders: Authority under "Distributed Knowledge" CKG Working Paper.

2003-8: Jens Gammelgaard and Torben Pedersen: Internal versus External Knowledge Sourcing of Subsidiaries - An Organizational Trade-Off.

2003-9: Kate Hutchings and Snejina Michailova: Facilitating Knowledge Sharing in Russian and Chinese Subsidiaries: The Importance of Groups and Personal Networks Accepted for publication in Journal of Knowledge Management.

2003-10: Volker Mahnke, Torben Pedersen and Markus Verzin: The Impact of Knowledge Management on MNC Subsidiary Performance: the Role of Absorptive Capacity CKG Working Paper.

2003-11: Tomas Hellström and Kenneth Husted: Mapping Knowledge and Intellectual Capital in Academic Environments: A Focus Group Study Accepted for publication in Journal of Intellectual Capital CKG Working Paper.

2003-12: Nicolai J Foss: Cognition and Motivation in the Theory of the Firm: Interaction or "Never the Twain Shall Meet"? Accepted for publication in Journal des Economistes et des Etudes Humaines CKG Working Paper.

2003-13: Dana Minbaeva and Snejina Michailova: Knowledge Transfer and Expatriation Practices in MNCs: The Role of Disseminative Capacity.

2003-14: Christian Vintergaard and Kenneth Husted: Enhancing Selective Capacity Through Venture Bases. 


\section{4}

2004-1: Nicolai J. Foss: Knowledge and Organization in the Theory of the Multinational Corporation: Some Foundational Issues

2004-2: Dana B. Minbaeva: HRM Practices and MNC Knowledge Transfer

2004-3: Bo Bernhard Nielsen and Snejina Michailova: Toward a Phase-Model of Global Knowledge Management Systems in Multinational Corporations

2004-4: Kirsten Foss \& Nicolai J Foss: The Next Step in the Evolution of the RBV: Integration with Transaction Cost Economics

2004-5: Teppo Felin \& Nicolai J. Foss: Methodological Individualism and the Organizational Capabilities Approach

2004-6: Jens Gammelgaard, Kenneth Husted, Snejina Michailova: Knowledge-sharing Behavior and Post-acquisition Integration Failure

2004-7: Jens Gammelgaard: Multinational Exploration of Acquired R\&D Activities

2004-8: Christoph Dörrenbächer \& Jens Gammelgaard: Subsidiary Upgrading? Strategic Inertia in the Development of German-owned Subsidiaries in Hungary

2004-9: Kirsten Foss \& Nicolai J. Foss: Resources and Transaction Costs: How the Economics of Property Rights Furthers the Resource-based View

2004-10: Jens Gammelgaard \& Thomas Ritter: The Knowledge Retrieval Matrix: Codification and Personification as Separate Strategies

2004-11: Nicolai J. Foss \& Peter G. Klein: Entrepreneurship and the Economic Theory of the Firm: Any Gains from Trade?

2004-12: Akshey Gupta \& Snejina Michailova: Knowledge Sharing in Knowledge-Intensive Firms: Opportunities and Limitations of Knowledge Codification

2004-13: Snejina Michailova \& Kate Hutchings: Knowledge Sharing and National Culture: A Comparison Between China and Russia

\section{5}

2005-1: Keld Laursen \& Ammon Salter: My Precious - The Role of Appropriability Strategies in Shaping Innovative Performance

2005-2: Nicolai J. Foss \& Peter G. Klein: The Theory of the Firm and Its Critics: A Stocktaking and Assessment

2005-3: Lars Bo Jeppesen \& Lars Frederiksen: Why Firm-Established User Communities Work for Innovation: The Personal Attributes of Innovative Users in the Case of Computer-Controlled Music

2005-4: Dana B. Minbaeva: Negative Impact of HRM Complementarity on Knowledge Transfer in MNCs

2005-5: Kirsten Foss, Nicolai J. Foss, Peter G. Klein \& Sandra K. Klein: Austrian Capital 
Theory and the Link Between Entrepreneurship and the Theory of the Firm

2005-1: Nicolai J. Foss: The Knowledge Governance Approach

2005-2: Torben J. Andersen: Capital Structure, Environmental Dynamism, Innovation Strategy, and Strategic Risk Management

2005-3: Torben J. Andersen: A Strategic Risk Management Framework for Multinational Enterprise

2005-4: Peter Holdt Christensen: Facilitating Knowledge Sharing: A Conceptual Framework

2005-5 Kirsten Foss \& Nicolai J. Foss: Hands Off! How Organizational Design Can Make Delegation Credible

2005-6 Marjorie A. Lyles, Torben Pedersen \& Bent Petersen: Closing the Knowledge Gap in Foreign Markets - A Learning Perspective

2005-7 Christian Geisler Asmussen, Torben Pedersen \& Bent Petersen: How do we Capture "Global Specialization" when Measuring Firms' Degree of internationalization?

2005-8 Kirsten Foss \& Nicolai J. Foss: Simon on Problem-Solving: Implications for New Organizational Forms

2005-9 Birgitte Grøgaard, Carmine Gioia \& Gabriel R.G. Benito: An Empirical Investigation of the Role of Industry Factors in the Internationalization Patterns of Firms

2005-10 Torben J. Andersen: The Performance and Risk Management Implications of Multinationality: An Industry Perspective

2005-11 Nicolai J. Foss: The Scientific Progress in Strategic Management: The case of the Resource-based view

2005-12 Koen H. Heimeriks: Alliance Capability as a Mediator Between Experience and Alliance Performance: An Empirical Investigation Into the Alliance Capability Development Process

2005-13 Koen H. Heimeriks, Geert Duysters \& Wim Vanhaverbeke: Developing Alliance Capabilities: An Empirical Study

2005-14 JC Spender: Management, Rational or Creative? A Knowledge-Based Discussion

\section{6}

2006-1: Nicolai J. Foss \& Peter G. Klein: The Emergence of the Modern Theory of the Firm

2006-2: Teppo Felin \& Nicolai J. Foss: Individuals and Organizations: Thoughts on a Micro-Foundations Project for Strategic Management and Organizational Analysis

2006-3: Volker Mahnke, Torben Pedersen \& Markus Venzin: Does Knowledge Sharing 
Pay? An MNC Subsidiary Perspective on Knowledge Outflows

2006-4: Torben Pedersen: Determining Factors of Subsidiary Development

2006-5 Ibuki Ishikawa: The Source of Competitive Advantage and Entrepreneurial Judgment in the RBV: Insights from the Austrian School Perspective

2006-6 Nicolai J. Foss \& Ibuki Ishikawa: Towards a Dynamic Resource-Based View: Insights from Austrian Capital and Entrepreneurship Theory

2006-7 Kirsten Foss \& Nicolai J. Foss: Entrepreneurship, Transaction Costs, and Resource Attributes

2006-8 Kirsten Foss, Nicolai J. Foss \& Peter G. Klein: Original and Derived Judgement: An Entrepreneurial Theory of Economic Organization

2006-9 Mia Reinholt: No More Polarization, Please! Towards a More Nuanced Perspective on Motivation in Organizations

2006-10 Angelika Lindstrand, Sara Melen \& Emilia Rovira: Turning social capital into business? A study of Swedish biotech firms' international expansion

2006-11 Christian Geisler Asmussen, Torben Pedersen \& Charles Dhanaraj: Evolution of Subsidiary Competences: Extending the Diamond Network Model

2006-12 John Holt, William R. Purcell, Sidney J. Gray \& Torben Pedersen: Decision Factors Influencing MNEs Regional Headquarters Location Selection Strategies

2006-13 Peter Maskell, Torben Pedersen, Bent Petersen \& Jens Dick-Nielsen: Learning Paths to Offshore Outsourcing - From Cost Reduction to Knowledge Seeking

2006-14 Christian Geisler Asmussen: Local, Regional or Global? Quantifying MNC Geographic Scope

2006-15 Christian Bjørnskov \& Nicolai J. Foss: Economic Freedom and Entrepreneurial Activity: Some Cross-Country Evidence

2006-16 Nicolai J. Foss \& Giampaolo Garzarelli: Institutions as Knowledge Capital: Ludwig M. Lachmann's Interpretative Institutionalism

2006-17 Koen H. Heimriks \& Jeffrey J. Reuer: How to Build Alliance Capabilities

2006-18 Nicolai J. Foss, Peter G. Klein, Yasemin Y. Kor \& Joseph T. Mahoney: Entrepreneurship, Subjectivism, and the Resource - Based View: Towards a New Synthesis

2006-19 Steven Globerman \& Bo B. Nielsen: Equity Versus Non-Equity International Strategic Alliances: The Role of Host Country Governance

\section{7}

2007-1 Peter Abell, Teppo Felin \& Nicolai J. Foss: Building Micro-Foundations for the Routines, Capabilities, and Performance Links 
2007-2 Michael W. Hansen, Torben Pedersen \& Bent Petersen: MNC Strategies and Linkage Effects in Developing Countries

2007-3 Niron Hashai, Christian G. Asmussen, Gabriel R.G. Benito \& Bent Petersen: Predicting the Diversity of Foreign Entry Modes

2007-4 Peter D. Ørberg Jensen \& Torben Pedersen: Whether and What to Offshore?

2007-5 Ram Mudambi \& Torben Pedersen: Agency Theory and Resource Dependency Theory: Complementary Explanations for Subsidiary Power in Multinational Corporations

2007-6 Nicolai J. Foss: Strategic Belief Management

2007-7 Nicolai J. Foss: Theory of Science Perspectives on Strategic Management Research: Debates and a Novel View

2007-8 Dana B. Minbaeva: HRM Practices and Knowledge Transfer in MNCs 